\title{
The Case against Antibiotics and for Anti-Virulence Therapeutics
}

\author{
Julia A. Hotinger (D), Seth T. Morris and Aaron E. May * \\ Department of Medicinal Chemistry, School of Pharmacy, Virginia Commonwealth University, \\ Richmond, VA 23219, USA; hotingerja@vcu.edu (J.A.H.); morriss3@vcu.edu (S.T.M.) \\ * Correspondence: aemay@vcu.edu
}

Citation: Hotinger, J.A.; Morris, S.T.; May, A.E. The Case against Antibiotics and for Anti-Virulence Therapeutics. Microorganisms 2021, 9 , 2049. https://doi.org/10.3390/ microorganisms 9102049

Academic Editors: Giuseppantonio Maisetta, Giovanna Batoni and Semih Esin

Received: 3 September 2021

Accepted: 24 September 2021

Published: 28 September 2021

Publisher's Note: MDPI stays neutral with regard to jurisdictional claims in published maps and institutional affiliations.

Copyright: (C) 2021 by the authors. Licensee MDPI, Basel, Switzerland. This article is an open access article distributed under the terms and conditions of the Creative Commons Attribution (CC BY) license (https:// creativecommons.org/licenses/by/ $4.0 /)$.

\begin{abstract}
Although antibiotics have been indispensable in the advancement of modern medicine, there are downsides to their use. Growing resistance to broad-spectrum antibiotics is leading to an epidemic of infections untreatable by first-line therapies. Resistance is exacerbated by antibiotics used as growth factors in livestock, over-prescribing by doctors, and poor treatment adherence by patients. This generates populations of resistant bacteria that can then spread resistance genes horizontally to other bacterial species, including commensals. Furthermore, even when antibiotics are used appropriately, they harm commensal bacteria leading to increased secondary infection risk. Effective antibiotic treatment can induce bacterial survival tactics, such as toxin release and increasing resistance gene transfer. These problems highlight the need for new approaches to treating bacterial infection. Current solutions include combination therapies, narrow-spectrum therapeutics, and antibiotic stewardship programs. These mediate the issues but do not address their root cause. One emerging solution to these problems is anti-virulence treatment: preventing bacterial pathogenesis instead of using bactericidal agents. In this review, we discuss select examples of potential antivirulence targets and strategies that could be developed into bacterial infection treatments: the bacterial type III secretion system, quorum sensing, and liposomes.
\end{abstract}

Keywords: antibiotics; anti-virulence; resistance; type III secretion system; quorum sensing; liposomes; commensal bacteria

\section{Introduction}

Before the serendipitous discovery of penicillin in 1929, the three leading causes of death in the United States were all infectious diseases: influenza, pneumonia, and tuberculosis [1,2]. Pathogenic bacteria, although no longer leading causes of death due to antibiotics, continue to be a global health threat, with a billion infections worldwide and nearly 15 million deaths every year [3-5]. The prevalence of antibiotic-resistant bacterial pathogens is a serious and growing problem. The CDC estimates that the rate of antibiotic-resistant infections in the United States has increased by $40 \%$ from 2014 to 2019 [6]. Moreover, the observance of resistance to each new antibiotic is never far behind the commercial release of the drug [6]. This contributes to a slowing of novel antibiotics coming to market, with $78 \%$ of major drug companies shown to decrease or stop antibiotic research between 1990 and 2019 [7].

Deleterious effects of antibiotic use, other than resistance, have become more well understood over time. Antibiotics can destroy commensal bacterial colonies, leading to an increased risk of infection and other health complications [8-10]. They may also induce bacterial SOS tactics, which can include toxin release and increased transfer of resistance genes [11,12]. Although there are mediation methods, such as combination therapies, narrow-spectrum antibiotics, and stewardship programs, the root cause of these issues is that antibiotics directly kill bacteria. An alternative to antibiotic treatments could be anti-virulence therapies. Anti-virulence therapies target the pathogenic mechanisms of bacteria rather than killing bacteria outright. In this review, we present lesser-known evidence of the detrimental effects of antibiotics and discuss promising anti-virulence 
targets and strategies. These targets and strategies include the bacterial type III secretion system [13-15], quorum sensing [16-18], and liposomes [19-21].

\section{Downsides of Broad-Spectrum Antibiotic Use}

Antibiotics have been crucial to the rise in life expectancy over the last century [22,23]. They are used to treat approximately 2.5-3 million infections per year in the US and are a hallmark of modern medicine [2]. Unfortunately, resistance to these agents is a growing problem, as $70 \%$ of infections are caused by pathogenic bacteria that contain at least one resistance gene [7]. In this section, we will review resistance as well as other downsides to the use of these agents that have also become more obvious in recent years. This includes the reduced ability to fight infections and other adverse side effects directly related to killing bacteria.

\subsection{Resistance}

\subsubsection{Proliferation and Mechanisms}

Resistance to antimicrobial agents is not a new process. For eons, bacteria have produced secondary metabolites for self-defense purposes to aid in their survival [24]. Bacteria that produce these antibiotic compounds have naturally become resistant to them, with resistance genes often being incorporated into gene clusters with the genes for the antibiotic itself. As one example, D'costa et al. discovered 30,000-year-old bacterial DNA that encodes resistance to $\beta$-lactam, tetracycline, and glycopeptide antibiotics [24]. There is also present in the environment a number of resistance genes, even in minimally human-impacted areas [25]. This 'intrinsic resistance' has been proposed to make up approximately $3 \%$ of the bacterial genome [26]. The spontaneous frequency of mutations conferring resistance to an antibiotic is $10^{-9}-10^{-6}$ dependent on species and strain, making resistance formation inevitable [27]. Now that humans have entered the evolutionary "arms race" with the clinical use of antibiotics, the prevalence of resistant bacteria is rising with the widespread use of these agents [28]. Davies and Davies have reviewed the resistance formation timeline to common FDA approved agents [29]. It is estimated that by the year 2050 that 10 million people will die from infections that can no longer be treated by available antibiotics [30].

Along with the natural borne resistance leaking into human-populated areas and reaching pathogenic bacteria, resistance can be spread through several other mechanisms (Figure 1). This includes resistance originating from the use (and often misuse) of antibiotics to treat active infection in humans or animals such as pets or livestock, as well as antibiotic use as growth factors in agriculture. From these two origins, antibiotic resistance genes can proliferate and spread within communities and around the world. It often starts when a member of a family obtains an infection (Figure 1A) and goes to a medical care facility (Figure 1B) to obtain an antibiotic to use as a treatment (Figure 1C). The family member takes the antibiotic as prescribed, but a small number of pathogenic bacteria survive due to resistance genes (Figure 1D). The immune system can kill off these pathogens, but not before they spread their resistance genes to commensal bacteria [31]. The patient then leaves the medical facility to return home, where they spread small numbers of the newly resistant commensal bacteria with family members, including their pets (Figure 1A) [32-34]. The pets then interact with wildlife nearby and spread the resistance genes into the nearby forest, creating a reservoir for the genes (Figure 1E) [32,35,36]. The family also decides to take a trip overseas to visit family, thereby spreading the resistant commensals to a new country (Figure 1G) [32]. 


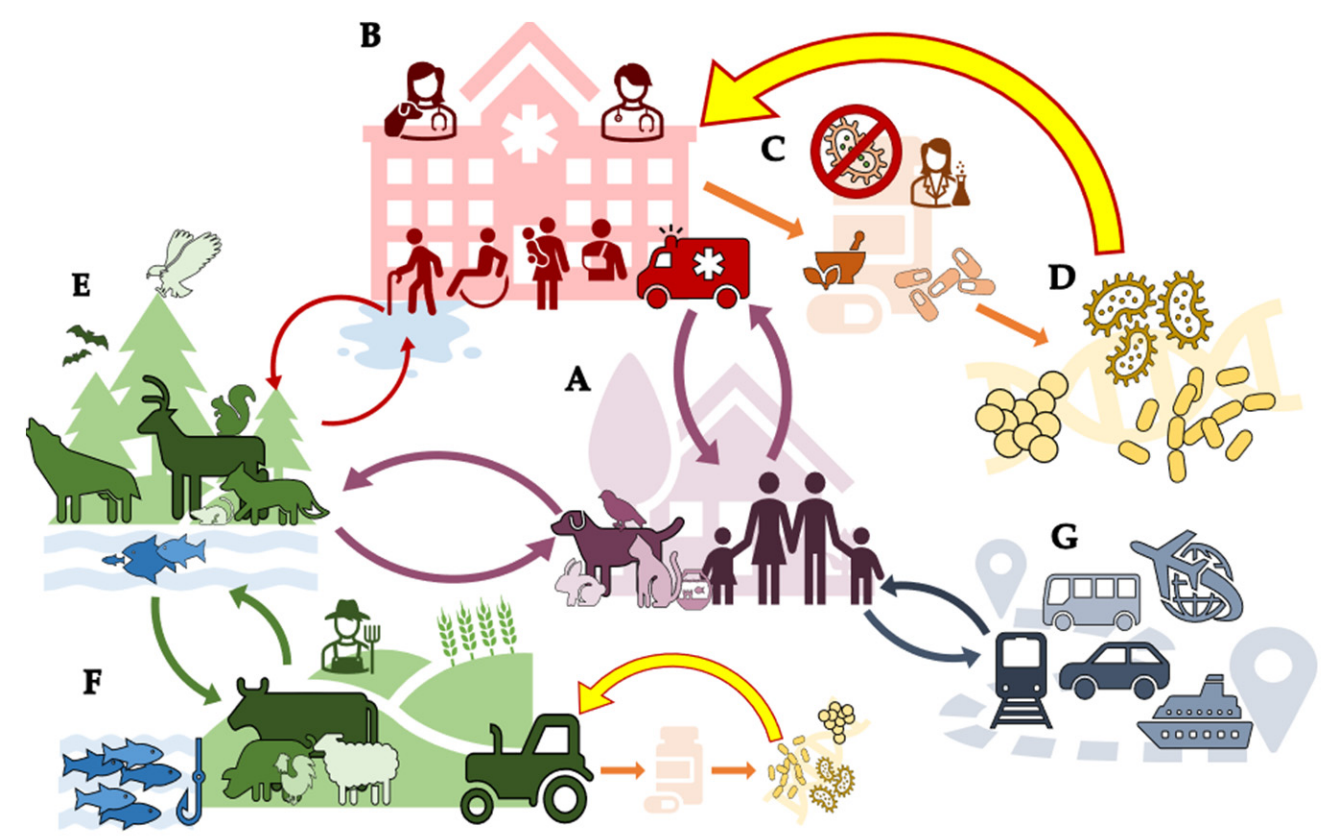

Figure 1. Mechanisms of resistance gene transfer and spread. (A) the greater community including the populace and their pets; (B) health care facilities including hospitals, long term care facilities, and other medical offices; (C) antibiotics prescribed by healthcare workers to treat infections; (D) bacteria mutates to become resistant to antibiotics; (E) wildlife serves as a reservoir for resistance genes obtained through pet interactions with animals (A), wastewater from health care facilities (B) and agriculture (F); (F) antibiotics are used as growth factors for livestock; and (G) travel can introduce resistance genes to communities where they were previously absent.

Resistance genes can also be exchanged between wildlife and livestock, meaning that they can transmit from one species to another, including the commensal bacteria of those animals [37]. Many industrial animals are reservoirs for bacteria commensal to the animal but are pathogenic to humans [38,39]. For example, pigs, chickens, and cattle are often carriers of Salmonella spp. and E. coli [40-42]. This pathogenic reservoir problem is worsened by the increased resistance genes found in animals. This is due to the use of antibiotics for growth promotion and prophylaxis leading to resistance genes to form at high rates among the bacterial populations within these animals (Figure 1F) [38,39]. As mentioned previously, wildlife and the environment can also serve as a reservoir for antibiotic resistance genes [39]. This can be due to interactions between companion animals with wildlife or due to pollution from health care facilities. Hospital wastewater is rife with antibiotics and their metabolites as well as bacteria. In one study by Yao et al., they found a $100 \%$ incidence rate of the antibiotic ofloxacin in the wastewater of three hospital wastewater treatment plants in China. There was also a high relative abundance of pathogenic bacteria (e.g., Acinetobacter, Klebsiella, Aeromonas, and Pseudomonas) in comparison to commensals [43]. This is especially troubling because antibiotic genes can be auto-replicative, meaning they increase over time [44,45].

Resistance to antibiotics forms even when they are used correctly, however, overprescription and misuse can accelerate the problem. Approximately $30 \%$ of antibiotics prescribed at emergent or urgent care facilities in the US are unnecessary [46], and in the UK approximately $50 \%$ of patients with respiratory tract infections (RTIs) are treated with antibiotics even though over 70\% of RTIs are viral [47]. In another study, it was discovered that some intensive care patients in South Africa were on up to 10 different antibiotics concurrently [48]. Many patients with RTIs directly request antibiotics as part of their care and physicians feel obligated to fulfill the request either to ensure patient satisfaction or to be over-cautious about the cause of infection [49]. 
Along with over-prescription of antibiotics, misuse of antibiotics is a large problem. Many patients do not adhere to the medication treatment as prescribed, often stopping the course after their symptoms are alleviated and discarding or saving the remaining pills. This is of particular importance when it comes to antibiotics, as storage of the unused medication often leads to self-medication at a later date when it is unnecessary, resulting in the increased emergence of bacterial resistance [50]. Approximately $28.5 \%$ of patients prescribed an antibiotic for an RTI are non-adherent to effective dosing with about $10.6 \%$ of those patients stopping the regimen before taking half of the doses given [51]. Of note, these negative trends increase with complexity and frequency of dosing. For example, of those given a three times-daily antibiotic regimen less than $10 \%$ had excellent adherence and less than $20 \%$ had acceptable adherence in comparison to $80 \%$ with excellent adherence for those given once-daily regimens [51].

The mechanism of resistance to antibiotics is highly versatile and dependent on the class of antibiotics used (Figure 2). Resistance to antibiotics is commonly thought of as point mutations to the antibiotic's target that prevent antibiotic binding (Figure 2C). Some bacteria have evolved enzymes that inactivate the antibiotic through chemical means or physical degradation (Figure 2D) or modify the antibiotic through methylation, acylation, phosphorylation, etc. that makes it unable to bind to the active site (Figure 2E). Bacteria could also become resistant by circumventing the pathway affected by the antibiotic by utilizing a separate pathway (Figure 2F). Bacteria can also become resistant to a broadspectrum of antibiotics by upregulating the production of efflux transporters (Figure 2G) and/or reducing permeability mechanisms (Figure 2H) [52-54]. Quinolones [55], tetracyclines [56,57], $\beta$-lactams [58], macrolides [59-61], and several other antibiotic classes are vulnerable to efflux by bacteria.

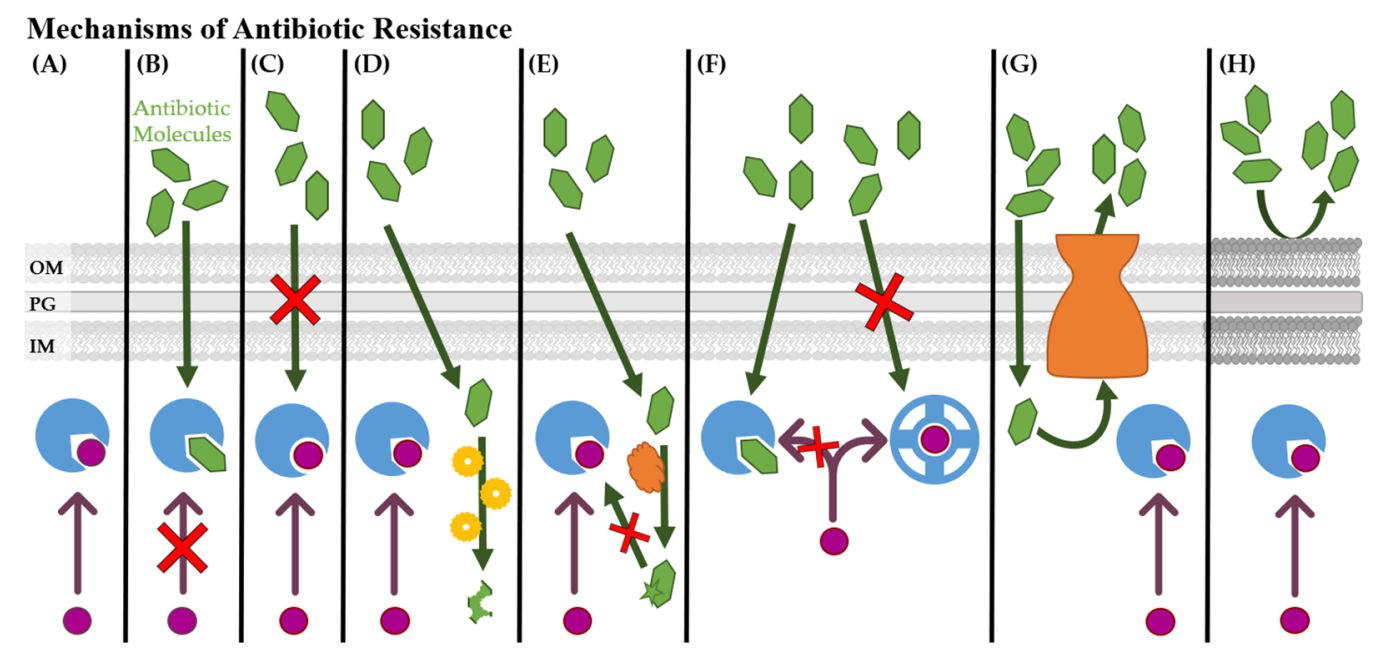

Figure 2. Mechanisms of antibiotic resistance. (A) Untreated bacterial infection; (B) Antibiotic treatment before resistance formation; (C) Mutation to the binding pocket to prevent antibiotic binding; (D) Recruitment of enzymes to degrade or inactivate the antibiotic; (E) Modification of antibiotic (e.g., methylation, acylation, phosphorylation, etc.) to prevent antibiotic binding; (F) Circumvention of the antibiotic target through a secondary pathway; (G) Upregulation of efflux pumps to remove the antibiotic; and (H) Decreasing cell permeability so the antibiotic does not reach MIC within the cell. Abbreviations: OM: Outer bacterial membrane; PG: Peptidoglycan; IM: Inner bacterial membrane.

Resistance mechanisms are often used in concert to achieve multidrug resistance, and dangerous multidrug-resistant (MDR) pathogens are increasingly becoming more prevalent. Klebsiella pneumoniae becomes highly resistant to drugs like imipenem, ceftazidime + avibactam, and temocillin with a combination of $\beta$-lactamase production, decreased porin production and increased efflux transporter expression [62,63]. Some strains of MDR P. aeruginosa have become resistant to all fluoroquinolones, carbapenems, and aminoglycosides [6,64]. 
Although antibiotic stewardship practices such as stricter guidelines for prescriptions, prescriber education programs, and delayed prescriptions can slow the spread of resistant bacteria, the resistance problem is not going away soon $[65,66]$. The Centers for Disease Control and Prevention (CDC) has identified several antibiotic-resistant bacteria as "urgent" threats, including Clostridioides difficile, carbapenem-resistant Acinetobacter, drug-resistant Neisseria gonorrhoeae, and carbapenem-resistant Enterobacteriaceae. Many others like drug-resistant Streptococcus pneumoniae and methicillin-resistant Staphylococcus aureus are classified as "serious" threats.

There is, however, a cost to the bacteria associated with developing these resistances [67]. Resistant bacteria often grow slower than their antibiotic-susceptible ancestors [68]. For example, bacteria may evolve hyper-accurate ribosomes to resist ribosomal targeting antibiotics. While this leads to less antibiotic binding, and thus antibiotic activity, the ribosome functions slower, leading to an attenuated growth rate [69]. Although rare, some bacteria have even become dependent on these antibiotics for their survival [70-72]. For example, a strain of $P$. aeruginosa was found to be dependent on the antibiotic sulfamethoxazole. Wolter et al. showed this dependence was due to changes made in the bacteria's membrane by sulfamethoxazole that allowed for the incorporation of an otherwise toxic phospholipid [70].

\subsubsection{Gene Transfer}

Bacteria can undergo natural selection to evolve resistance genes when placed under selective pressure by an antimicrobial compound. This is known as vertical gene transfer (VGT). Bacteria can also transfer their genetic material, including their resistance genes, to other populations of bacteria by transformation, transduction, or conjugation [73]. This process is known as horizontal gene transfer (HGT). The use of HGT mechanisms means that a bacterial population that has never been exposed to a particular antibiotic may still become resistant to it. For example, it is believed that the gene causing vancomycin resistance in vancomycin-resistant S. aureus (VRSA) originally developed in Enterococcus faecalis and was later transferred via HGT to S. aureus strains [74].

Not only do antibiotics apply selective pressure, but they may also increase the rate at which mutations occur by inducing HGT, aiding bacteria in the development of subsequent antibiotic resistance (Figure 3) [75-77]. Antibiotics can also select for bacteria that have a higher rate of mutation, essentially training them to develop resistance faster [78]. For instance, treatment with sub-MIC fluoroquinolones and dihydrofolate reductase inhibitors promotes the transfer of plasmids conferring resistance to chloramphenicol, sulfamethoxazole, trimethoprim, and streptomycin [12]. Stress from certain antibiotics, or combinations thereof, can also induce the SOS response in some bacteria which exponentially increases conjugation efficiency [75]. Zhang et al. demonstrated this by showing the dramatic effect of certain combinations of low doses of antibiotics on the transfer of an RP4 plasmid between two E. coli strains (Figure 3A) [75]. More evidence of this phenomenon was observed when Prudhomme et al. showed that antibiotic stress from multiple classes of bacteria-induced genetic transformability in Streptococcus pneumoniae, a bacterium that does not have an SOS-response [76]. They tested four different antibiotics (mitomycin, norfloxacin, kanamycin, and streptomycin) at sub-therapeutic concentrations and found that they all induced the production competence-stimulating peptide (CSP) as monitored by luciferase assay (Figure 3B). 
(A) Antibiotic/SOS-Induced Conjugation

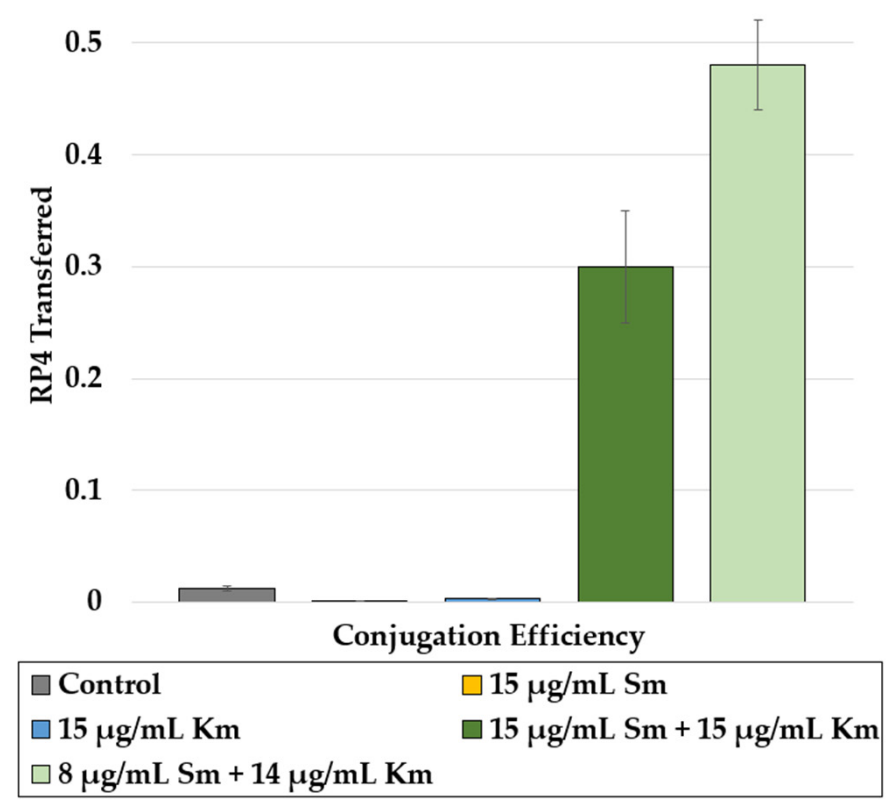

(B) Non-SOS Antibiotic-Induced Conjugation

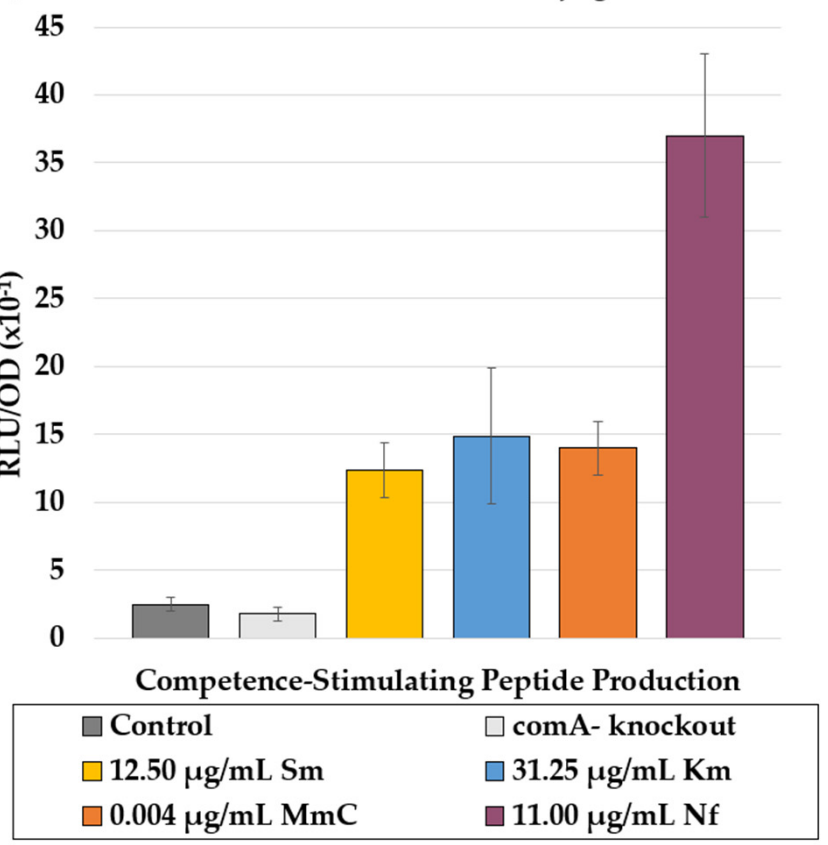

Figure 3. Genetic transformability/competence induced by antibiotic stress. (A) Antibiotic-induced SOS response-related increase in conjugative efficiency in E. coli after a $20 \mathrm{~h}$ incubation. (B) Luciferase activity indicating levels of CSP as controlled for by S. pneumoniae cell growth after $70 \mathrm{~min}$ in the presence of sub-therapeutic concentrations of multiple antibiotics. Abbreviations: Sm: Streptomycin; Km: Kanamycin; MmC: Mitomycin C; Nf: Norfloxacin. Data from [75,76].

\subsection{Reduced Ability to Fight Infections}

One of the major downsides to antibiotic use is a reduction in the ability to fight infection after treatment, mainly due to the collateral killing of commensal bacteria. This phenomenon was demonstrated in 1950 when Terramycin proved to alter the gut microbiota in patients undergoing bowel surgery $[79,80]$. Antibiotics are often prescribed during hospital stays for severe infection treatment or infection prevention after surgery or in those immunocompromised. This high abundance of antibiotics and co-locality of many pathogenic bacteria within a hospital environment contributes to over 1.7 million hospital-acquired infections every year and over 100,000 deaths in the US [81]. Changes to gut microbiota due to antibiotic use, such as total volume loss and species composition ratio disruption, can last for years after the exposure [82,83] and the loss of certain commensals can be permanent [84]. One study by Roubaud-Baudron et al. indicates that early-life antibiotic exposure can increase susceptibility to infection later in life as well as increase infection severity for infections obtained during adulthood [8]. This is of particular significance as children are prescribed more antibiotics than adults $[85,86]$.

The main cause for increased risk of infection after antibiotic treatment is the loss of total volume of commensal bacterial populations throughout the body, especially in the gastrointestinal tract. In normal circumstances, these commensals provide competition that keeps opportunistic pathogens in check [87]. When they are lost or significantly reduced, other species of bacteria can flourish in this niche. This phenomenon is well understood, but the extent of the problem is often not appreciated. The infectious dose of Salmonella enterica required to infect $50 \%$ of mice $\left(\mathrm{ID}_{50}\right)$ is typically upwards of $10,000,000$ individual cells. However, $24 \mathrm{~h}$ after a singular treatment of $10 \mathrm{mg} / \mathrm{kg}$ of the antibiotic streptomycin, the $\mathrm{ID}_{50}$ of $S$. enterica is reduced to $<10$ cells (Figure 4) [88]. In context, this is the difference between eating an entire improperly cooked infected chicken breast to touching a properly washed cutting board [89]. 


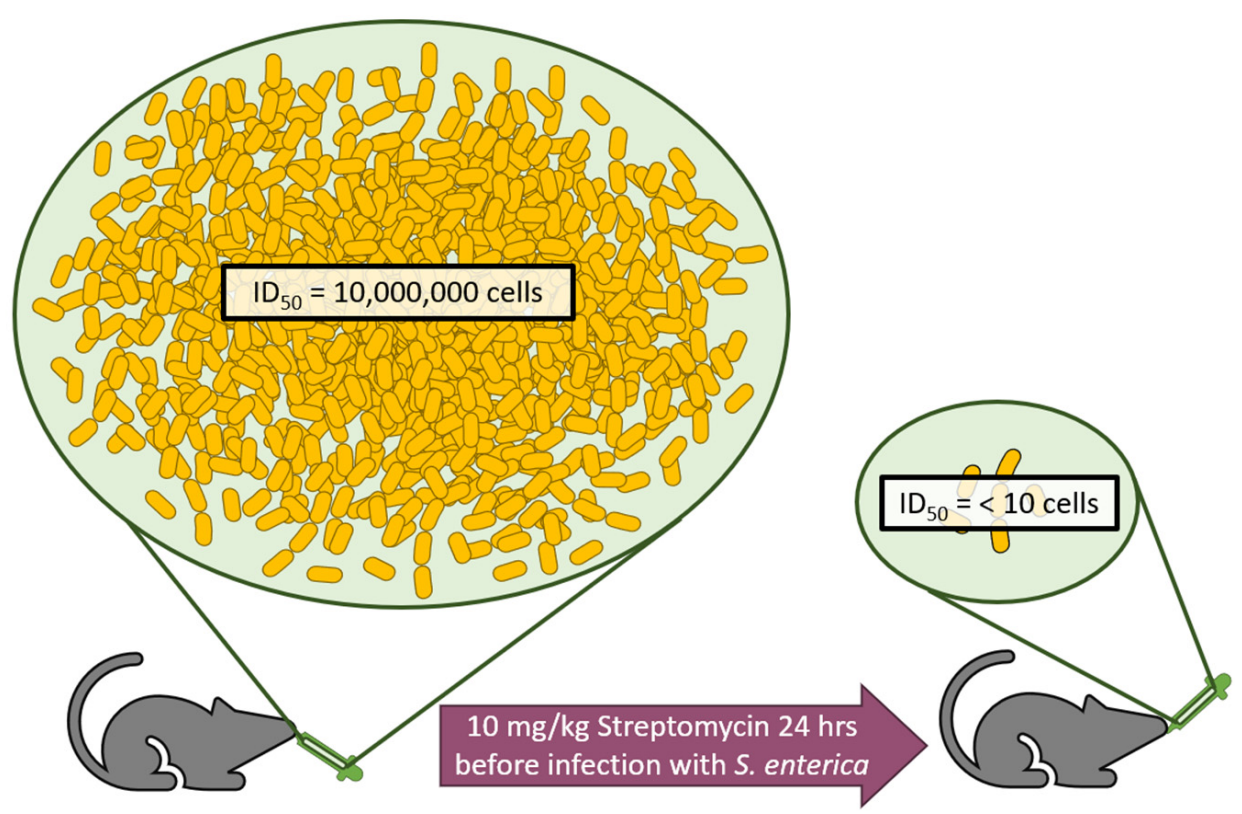

Figure 4. The effect of antibiotics on the $\mathrm{ID}_{50}$ of pathogenic bacteria. Data from [88].

It has also been shown that acute antibiotic exposure increases the risk of traveler's diarrhea (caused most commonly by Salmonella spp., Campylobacter spp., and enterotoxigenic Escherichia coli) for a year or more after treatment and multiple treatments in a short time can prevent the recovery of the microbiome indefinitely [90]. The odds of having received antibiotic treatment within 3 months before a Salmonella infection is twice that of baseline and is $50 \%$ higher for a year [91]. This is of particular importance because food-borne bacterial infections, such as traveler's diarrhea, are of a higher likelihood to carry resistance genes [31]. For example, approximately one-third of the two most common species of Campylobacter are resistant to ciprofloxacin ( $28 \%$ of C. jejuni and $38 \%$ of C. coli) and a study by Koningstein et al. showed overall Campylobacter resistance to fluoroquinolones was $21.7 \%$ and to macrolides was $2.3 \%$ [92].

The importance of these commensals in preventing secondary infection and disease is through simple competition as well as their assistance in host metabolism [31,84]. For example, many commensal bacteria are responsible for converting primary bile acids produced in the liver (cholic acid and chenodeoxycholic acid) into secondary bile acids (deoxycholic acid, lithocholic acid, and others). These bile acids play a role in secondary infection risk, like $C$. difficile infections (CDI). Higher levels of primary bile acids correlate with higher CDI rates in patients. In comparison, healthy patients typically have more secondary bile acids than primary [93,94]. It has also been shown that bile acids have both direct and indirect antimicrobial effects on the gut microbiome composition and volume $[95,96]$. The majority of antibiotics are known to decrease the number of bile acid-converting bacteria in the human gut [97].

Modulation of gut bacteria is not inherently malicious to host outcomes. For example, two clinically effective drugs for treating diabetes, metformin and berberine, modulate the gut microbiota and may contribute to beneficial effects on the host. Both drugs alleviated the negative effects of high-fat diet-induced changes by reducing gut microbial diversity, but increasing short-chain fatty acid (SCFA)-producing bacteria (Allobaculum, Bacteroides, Blautia, Butyricicoccus, and Phascolarctobacterium) were increased [97]. It is known that increased production of SCFA's contribute to cardiovascular health and provide anti-obesity effects $[98,99]$. Antibiotics such as ampicillin, on the other hand, have been shown to decrease these bacteria, which reiterates the detrimental effect they have on the human microbiome [100]. 


\section{Case Study: Clostridioides difficile Infection (CDI)}

In 1974 , it was seen that $21 \%$ of patients treated with clindamycin (a lincosamide) developed diarrhea and $50 \%$ of those with diarrhea had pseudomembranes in their feces-a sign of CDI [101]. In the US alone, $C$. difficile cases required approximately 224,000 hospitalizations and caused at least 12,800 deaths in 2017 [102,103]. This high incidence is partly due to the significant number (estimates range from 3-26\%) of people who are asymptomatic carriers of the pathogen [6]. C. difficile is a spore-forming bacteria, making it resistant to heat, $\mathrm{UV}$, and many antibiotics. Disease symptoms, mainly caused by toxins $\mathrm{A}$ and $\mathrm{B}$, range from diarrhea and fever in mild cases to colitis, toxic megacolon, multiorgan failure, and even death in more severe cases [104]. In total, $10-30 \%$ of patients have recurrent infections with increased risk after each occurrence $[105,106]$, and $20 \%$ of cases go undiagnosed due to lack of clinical suspicion or sub-optimal laboratory methods [107].

Antibiotic exposure, especially by penicillins, cephalosporins, clindamycin, and fluoroquinolones, is the highest risk determinant for CDI, with an 8-10 fold higher risk of CDI during treatment and 3-fold higher for 2 months after treatment [108,109]. Other significant factors include hospital stay length [110-112], age [108,113], and asymptomatic carriage $[109,110,114-116]$. CDI is becoming harder to treat over time due to a multitude of factors. Metronidazole is a 1st line treatment for CDI and currently has a clinical cure rate of $\sim 66 \%$ [117], with $>20 \%$ of infections being non-responsive [118,119]. Further exacerbating factors include increases in recurrent CDI rates [119] and the emergence of hypervirulent strains [120]. For example, the hypervirulent strain NAP1/027 represented $0.2 \%$ of all cases before 2001 [121], but now represents 51\% in the US [122] and 84\% in Canada [121].

Some new treatments have shown promise against CDI. Bezlotoxumab, an antitoxin B monoclonal antibody, was FDA approved in 2016 as a combination therapy with antibiotics for the treatment of CDI [123]. Fidaxomicin is a narrow-spectrum antibiotic that was FDA approved for CDI treatment in 2011. It targets only Gram-positive bacteria, shows a low physiological effect on gut flora, and has been shown to decrease recurrent infection $[124,125]$. These medications are promising CDI treatments that are important developments for infection treatment, however, they do not address the root cause of the infections. Fecal microbiota transplants (FMT) have recently been used to decrease risk and treat recurrent CDI. FMT has been shown to be more effective at treating CDI than vancomycin when administered via nasoduodenal tube [126] and colonoscopically [127].

\subsection{Adverse Side-Effects}

In the US alone there were a reported 142,505 emergent care visits for drug-related adverse events that were traced to antibiotic use [128]. In addition, $20 \%$ of all hospitalized patients who received an antibiotic experienced an adverse drug event [129], and antibioticassociated diarrhea (ADD) affects an estimated 5-39\% of antibiotic users [10]. Although the majority of these can be contributed to allergic reactions (nearly $80 \%$ ), a significant portion were due to other adverse effects [128]. These effects can be the result of bacterial survival tactics (often called SOS responses) induced by the antibiotic itself.

\subsubsection{Bacterial SOS Response Induction by Antibiotics}

A prototypical example of an SOS response is the increased production of Shiga toxin by Shigella spp. or Shiga toxin-producing E. coli (STEC) in reaction to environmental factors, including antibiotic treatment [130]. Shiga toxin (Stx) is one of the most potent biological exotoxins known. A single molecule of Stx is sufficient to kill a human cell via protein synthesis inhibition and eventual apoptosis [131]. Systemic exposure to Stx causes fluid accumulation in ileal loops and renal damage in animal models and is lethal when injected directly. Humans infected with Stx-producing bacteria manifest in hemolytic uremic syndrome (HUS), a disease characterized by a triad of symptoms that all stem from the apoptotic mechanism of Stx: reduced serum platelet levels (thrombocytopenia), hemolytic anemia, and renal damage [132-134]. 
Although Stx is consistently produced by Shigella spp. and STEC, the rate of that production can be exponentially increased when the bacterial population is exposed to antibiotics that activate their SOS responses. This effect was demonstrated by Zhang et al. in E. coli O157:H7 in vitro (Figure 5) [135]. Three hours after $30 \mathrm{ng} / \mathrm{mL}$ ciprofloxacin addition to an E. coli culture there was a 17-fold increase in Stx concentration (Figure 5B). They did find, however, that not all antibiotics tested caused the SOS response (e.g., Fosfomycin). They then tested the effect of inducing bacterial SOS response has on survival in vivo.
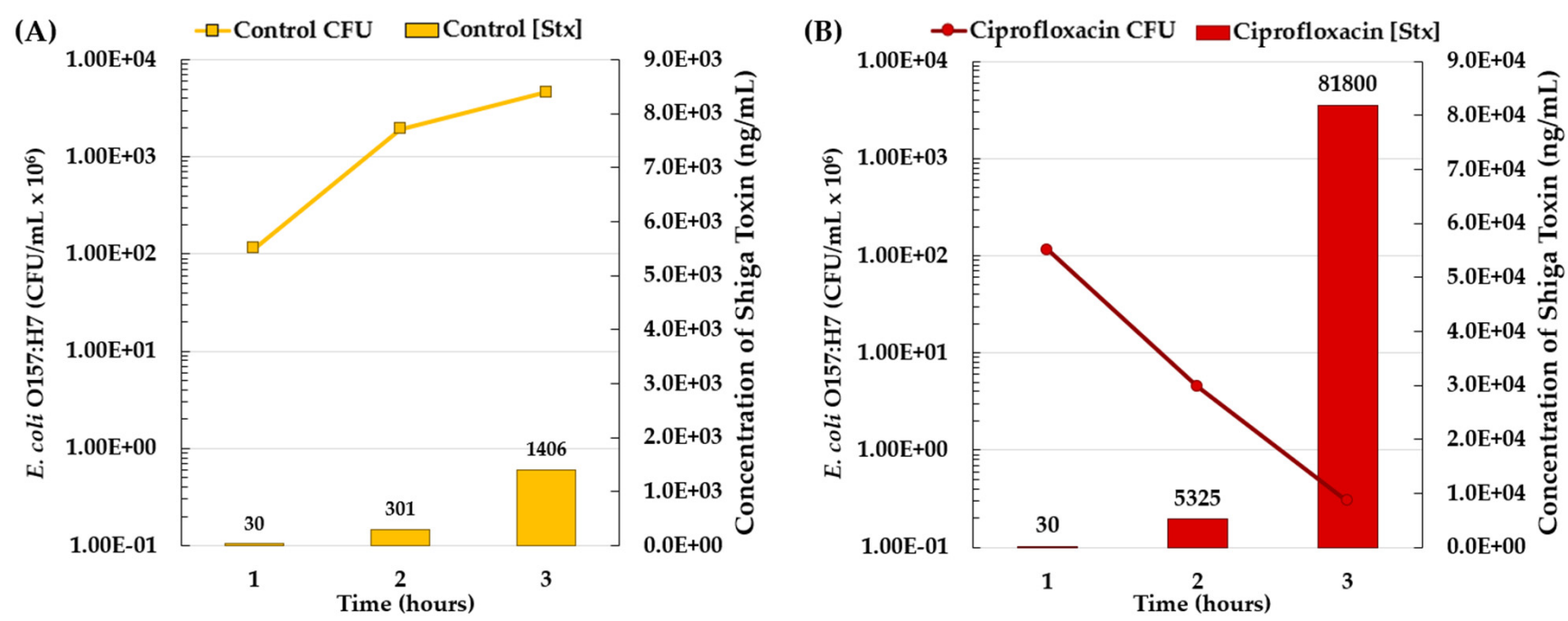

Figure 5. Shiga toxin induction by antibiotic use in E. coli. (A) As pathogenic E. coli grows there is a slight increase in Shiga toxin observed (yellow). (B) When ciprofloxacin is used to eliminate the bacteria, the surviving bacteria have an SOS response that includes over-production of Shiga toxin (red). Data from [135].

After treatment with ciprofloxacin, there was a 3-fold decrease in fecal CFUs in comparison to the PBS control group. In contrast, mice treated with ciprofloxacin had an increase in fecal Stx in comparison to the control mice. Of note, the mice with the highest fecal Stx levels died. These mice included $67 \%$ of the ciprofloxacin-treated mice and none of the control mice [135]. Every year in the US there are approximately 17,000 shigellosis and 18,500 STEC-caused deaths [2]. The majority of these deaths occur after the patient has undergone treatment which lends to the question: Were the deaths caused by the infection or by complications induced by antibiotic treatment, such as toxins released through bacterial SOS responses?

\subsubsection{Endotoxin Release after Antibiotic Treatment}

Exotoxins, such as Stx, are actively secreted by bacteria. Some endotoxins are only released from bacterial cells when it is disrupted or lysed, such as by antibiotics [136]. These toxins are often lipopolysaccharides (LPS) on the exterior of Gram-negative bacteria, with three distinct regions: Lipid A, an $\mathrm{R}$ polysaccharide, and an $\mathrm{O}$ polysaccharide. Bordetella pertussis, Escherichia coli, Enterobacter spp., Klebsiella spp., Neisseria spp., Salmonella spp., Shigella spp., Proteus spp., Pseudomonas spp., and Vibrio cholerae are all pathogenic endotoxin-producing bacteria [136,137]. Symptoms of endotoxin exposure range from fever, changes in white blood cell counts, disseminated intravascular coagulation, and hypotension, to shock and death. Injection of fairly small doses of endotoxin results in death in most mammals with disease progression following a regular pattern: (1) latent period; (2) physiological distress (diarrhea, prostration, shock); (3) death [136]. These toxins are also unable to be destroyed by boiling or distillation, making them very difficult to remove from wastewater and multiuse medical devices $[136,138]$. The FDA has a bacterial endotoxin limit of $0.5 \mathrm{EU} / \mathrm{mL}$ for medical devices and $0.25 \mathrm{EU} / \mathrm{mL}$ for sterile injectables [137], but deadly contamination still occurs [134]. 
Endotoxins are of particular importance when discussing antibiotics as the majority of antibiotics cause the release of these endotoxins upon bacterial cell death $[136,139,140]$. The Jarisch Herxheimer reaction (JHR) is specifically characterized as occurring within $24 \mathrm{~h}$ of antibiotic treatment of a spirochete infection and usually manifests as fever, chills, rigors, nausea and vomiting, headache, tachycardia, hypotension, hyperventilation, flushing, myalgia, and exacerbation of skin lesions [139]. Penicillins, tetracyclines, erythromycin, cephalosporins, levofloxacin, ciprofloxacin, clarithromycin, meropenem, and azithromycin can all cause JHR [139]. In sepsis, bacterial endotoxin exposure results in complications such as adult respiratory distress syndrome disseminated intravascular coagulation, and shock [141], often observed only after antimicrobial therapy has been administered [142]. In these cases, the antibiotic therapy causes a release of bacterial endotoxins and results in a Jarisch Herxheimer-like reaction [139,140].

\subsection{Current Mediation Methods}

Mediation methods, such as combination therapies, point of care and resistance susceptibility testing, narrower-spectrum therapies, and antibiotic stewardship programs have been used to mitigate issues that arise due to antibiotic use, such as resistance, reduced ability to fight infection, and adverse side effects [65,66,143-147]. These often help to prevent prolonged infections resulting from ineffective treatment or target specific bacterial infections to reduce side effects [148].

\subsubsection{Combination Therapies / Adjuvating}

Combination therapy consists of using a cocktail of antibiotics and adjuvants with different mechanisms and/or spectrums of action. This is to ensure the elimination of the pathogen by overwhelming or circumventing the potential resistance mechanisms present in the patient $[149,150]$. Unfortunately, this can result in additional resistance gene formation in the commensal bacteria of the patient, resulting in an inability to treat infections with those antibiotics in the future [151]. These combinations are often carried out using antibiotics that are not otherwise used in treatment due to harsh side effects or toxicity risks [152]. Many of these harsher antibiotics and/or antibiotic combinations also have to be administered via IV injection, resulting in higher discomfort to the patient than if the doses could be taken orally [151,152]. This also means the time a patient must remain in a hospital is increased as they have to stay for the duration of the treatment, again raising their risk for secondary infection and mortality [110-112]. Another downside to combination therapy is the potential to increase the risk and severity of side effects. Allison et al. showed that using a combination therapy of piperacillin-tazobactam or vancomycin-cefepime resulted in an $>150 \%$ increase in kidney disease in comparison to vancomycin monotherapy [153].

Combination therapies also include combining antibiotics with adjuvating compounds that increase the efficacy of the antibiotic through different methods. One common example of this is the use of $\beta$-lactamase inhibitors in combination with $\beta$-lactam antibiotics. Clavulanic acid, sulbactam, and tazobactam are all commonly irreversible $\beta$-lactamase inhibitors that act as suicide substrates, covalently binding to the $\beta$-lactamase active site so it is no longer functional [154]. Ceftolozane is a 5th generation cephalosporin that was FDA approved in 2014 and is paired with tazobactam for treatment [155]. Advances in this technology have also led to singular chemical moieties that can perform both antibiotic and anti- $\beta$-lactamase activities. One such example of this is Cefiderocol, which was FDA-approved in 2019 [156]. On the other hand, some clinicians are using combinations of multiple synergistic molecules to improve the efficacy of antibiotics. Recarbrio was also FDA approved in 2019 and is a combination of imipenem, cilastatin (renal dehydropeptidase inhibitor), and relebactam ( $\beta$-lactamase inhibitor) [156].

Another common combination prescribed with antibiotics is prebiotics or probiotics. Prebiotics work by providing food and/or resources for the remaining commensal bacteria to help with recolonization [157]. For example, human milk oligosaccharides are known 
to help restore the balance between Firmicute and Bacteroidetes commensals following antibiotic therapy [158]. Probiotics are live populations of commensal bacteria that are given to patients to help recolonize the patient, resulting in a reduced risk of secondary infections and assisting in out-competing pathogenic bacteria $[159,160]$. There is debate as to the efficacy of probiotics due to the high degree of variability in their administration. However, a meta-analysis of probiotic use with antibiotics to treat acute diarrhea in children "supports the potential beneficial roles of probiotics and symbiotics for acute diarrhea in children" [161]. At least two independent studies have shown the use of Lactobacillus rhamnosus GG was able to successfully decolonize patients with vancomycin-resistant enterococci [162,163]. Prebiotics and probiotics have also shown additive effects when used in concert [164]. These types of treatments are often helpful in reducing the risk of secondary infection, especially when treating gastrointestinal infections, but once again do not completely eliminate the problem $[159,160]$.

\subsubsection{Point of Care and Resistance Susceptibility Testing}

Point of care testing (POCT) and resistance susceptibility testing are other strategies that have grown in popularity as a method of mediating the side effects of antibiotic use. In this review, a medical test is considered point of care if it meets two criteria: it is performed near where the patient is being seen and it takes $15 \mathrm{~min}$ or less to obtain results. They are often carried out in a manner that allows a patient to be examined, tested, and prescribed within the same visit [165]. These methods help clinicians to decide the specific treatment regimens by elucidating the specific pathogen and/or any resistances that the pathogen may be harboring [166]. Widespread access to POCT can reduce the number of incorrect diagnoses and therefore misprescribed antibiotics. For example, access to a POC malaria rapid diagnostic test in Zambia led to a four-fold reduction in inappropriate antimalarial prescribing [48]. The use of POCT in primary care has increased by 45\% from 2004 to 2013 and has continued to grow in popularity [167].

Many hospitals only offer POCT or resistance susceptibility testing after a patient has shown negative progress during a first-line treatment due to the costs associated with the time, personnel, and equipment associated with performing these tests [165]. This also means that there is a disparity in the clientele that can have the tests performed, leading to a high degree of socioeconomic discrepancy in access [165,167-169]. Weihser and Giles showed that an increase in the use of POCT in ambulatory care, in essence, an earlier timepoint, reduces the overall number of patient bed days spent in the hospital. This overall reduces the financial and workload burden on the health care facility. These reductions lead to better overall health outcomes as patients with severe disease were not delayed in their transfer to ICU or other relevant units [170].

There is a significant problem of quality control in terms of the testing itself. These tests are often performed by in-house laboratory staff and/or by an external laboratory that is closely associated with the health care facility in question. These facilities and tests are not regulated to the same degree that medications or medical devices are. This leads to a lacking of safeguards for their accuracy and efficacy [171]. For example, in 2018 Saraswati et al. found significant heterogeneity in POCT for the diagnosis of scrub typhus, a disease caused by the bacterium Orientia tsutsugamushi. There was a pooled sensitivity rate of $66.0 \%$ due to the wide array of methodology and variation in quality of the tests offered to patients [172]. The same quality control issues are seen in viral focused POCT as well. Mak et al. reported the sensitivity of a SARS-CoV-2 rapid diagnostic test was potentially as low as $11.1 \%$, even though the manufacturer had claimed it to be $98 \%$ [173]. This lack of quality control and regulation leads to potentially thousands of false-negative tests and increased spread of disease [171].

\subsubsection{Narrow Spectrum Treatments}

Narrow-spectrum antibiotics have a lower complication risk as they target only a subset of bacteria [143]. Narrow spectrum antibiotics are subject to much lower levels 
of selective pressure because they target specific bacterium [143-146]. In theory, this will decrease the speed of resistance formation and proliferation [145]. They also help to prevent disease by keeping more human commensal flora intact in comparison to broad-spectrum antibiotics [146]. This targeted approach can allow for higher doses to be used which may reduce the treatment time [143]. They also often require diagnostic testing to determine bacterial species, and occasionally even strain. This can lead to an increased total time the patient has an infection before receiving treatment [144].

Bacteriophages are viruses that selectively target and infect bacteria. When employed as therapeutics, they work similarly to narrow-spectrum antibiotics as they can be genetically modified to be host-specific. Bacteriophages are viruses at their core, allowing them to multiply inside the bacteria and be released upon lysis. This can result in an increasing number of phages over time, a vital phenomenon not observed in other antimicrobial treatments [174]. Studies have demonstrated phage therapy effectively treats infections caused by resistant bacteria such as Listeria monocytogenes, Campylobacter jejuni, and Salmonella spp. In 2006, the FDA approved the use of a combination of six phages to be sprayed on ready-toeat meat and poultry to eliminate L. monocytogenes [175]. Bacteriophages can have similar effects to prophylactic antibiotic use and have been explored as replacements for antibiotics that are used as growth factors in livestock production [176-178]. Quality control and standardization of bacteriophage therapies have been a persistent and difficult challenge. The high specificity of bacteriophages makes them not suitable for patients with multiple infections or those with infections unable to be identified by diagnostic testing. In addition, phage resistance emerges quickly, necessitating the use of a cocktail of phages to slow resistance formation [177]. Bacterial exo- and endotoxins can be encoded by bacteriophages for various reasons [179]. These genes can be transferred to commensal bacteriophages and bacteria, leading to a potential for metabolic endotoxemia [180].

\subsubsection{Antibiotic Stewardship Case Study: Choose Wisely Canada ${ }^{\mathrm{TM}}$}

Antibiotic stewardship programs that have become a common way that governments can distribute information and recommendations regarding antibiotic use. This includes the Choose Wisely ${ }^{\circledR}$ program in the United States [181], Start Smart-Then, Focus in the United Kingdom [182], and national action plans in other countries [183-188]. In 2014, Canada implemented an initiative, called Choose Wisely Canada ${ }^{\mathrm{TM}}$, that endeavors to reduce unnecessary testing and treatments in healthcare [189]. Included in this initiative is a campaign to use antibiotics more sparsely and/or only when necessary. As such this program's successes and difficulties will be examined as a case study for antibiotic stewardship programs. There are over 15 recommendations developed by Canadian national clinician societies that encourage the judicious use of antibiotics that fall into five major categories: 1. Reduce antibiotics for urinary tract infections (UTI) in older people; 2. Treating sinus infections: Don't rush to antibiotics; 3 . Colds, flu, and other respiratory illnesses: Don't rush to antibiotics; 4. Preventing infections in the hospital: Watch out for these two practices; and 5. Sometimes no antibiotic is the best prescription [190].

Approximately $50 \%$ of older adults have bacteria in their urine that is not considered a contributing factor to UTIs [191]. This results in a high incidence of misdiagnosis due to common diagnosis testing for UTIs, such as dipstick testing and urine culture [191-193]. These techniques test for the presence, or lack, of bacteria and do not discriminate between pathogenic or commensal/mutualistic bacteria [194]. Many patients with positive dipstick tests will not exhibit symptoms of infection, such as fever, painful urination, dysuria, or urination frequency changes [191]. The Use Antibiotics Wisely campaign suggests refraining from the administration of dipstick, urine culture, or urinalysis tests as a means of UTI diagnosis in older adults. Instead they suggest observing symptoms and treating as they appear, not preemptively when bacteria is found in urine [190].

Up to $50 \%$ of antibiotics prescribed for respiratory tract and sinus infections in nonhospital settings are unnecessary [46,47]. Most respiratory, sinus, and ear infections are caused by a virus and as such an antibiotic will not be effective as a treatment, yet patients 
often insist on a prescription even when not required [195,196]. To combat this, Choose Wisely Canada ${ }^{\mathrm{TM}}$ is suggesting spending more time educating patients on the potential side effects of antibiotic use, such as stomach problems, dizziness, or rashes, to discourage patients from insisting on antibiotic use as well as prescribing delayed prescriptions that can reduce overall numbers of prescriptions filled $[190,197]$. A delayed prescription is a prescription that falls into the following categories: 1 . Re-contact-the practice by phone to request a prescription; 2 . Post-dated prescription; 3 . Collection-placement of prescription at reception; and 4. Patient-led-giving the patient a prescription with advice to delay. Approximately $30 \%$ of patients given a delayed prescription fill it as opposed to nearly $90 \%$ of patients given a non-delayed prescription [198,199].

Hospitals are one of the most common places where overprescription and overtreatment occur and are a breeding ground for superbugs [81]. Choose Wisely Canada ${ }^{\mathrm{TM}}$ has pointed out two main over-used medical practices that can increase the risk of infection in hospitals to increase public awareness: urinary catheters and ulcer drugs [190]. The risk of infection increases significantly after a urinary catheter is in place for two days. They are commonly used after surgery but are often left in longer than necessary for the convenience of staff. Ulcer drugs, such as proton-pump inhibitors and histamine $\mathrm{H} 2$ receptor antagonists, are used to prevent stress ulcers and gastrointestinal bleeding, but up to $75 \%$ of patients prescribed these drugs after a hospital stay do not need them [200]. These drugs can kill off commensal bacteria, thus increasing the risk for opportunistic pathogenic infections. One study showed that patients on ulcer drugs are approximately twice as likely to obtain C. difficile infections [200].

The success of these programs is difficult and complex to measure. A study by Tannenbaum et al. showed that after an educational intervention that was part of the Choose Wisely Canada ${ }^{\mathrm{TM}}$ initiative $62 \%$ of patients initiated a conversation with their physician or pharmacist regarding the medication in question. This resulted in $27 \%$ of them changing their care plans, as opposed to $5 \%$ of patients who did not receive the intervention [201]. Another study found a $41 \%$ decrease in overall laboratory tests since the program start, resulting in an estimated $\$ 215,000$ in savings while maintaining the quality of care [202]. Unfortunately, the cost-saving aspect of the program has garnered some criticism, as some view the initiative as a cost-cutting method at the expense of the patient, undermining the physician-patient relationship and trust [203]. Others have criticized the initiative for being too simplistic and only emphasizing "agreed-upon, well-established practices" [204], or claim the multiple guidelines for each topic will result in burnout and confuse physicians as to which protocol to follow [205]. The overall goal of this initiative has been effective at reducing "just in case" testing and treatment but its long-term impact on mitigating the downsides associated with antibiotic use has yet to be seen.

\subsubsection{Infection Prevention Measures Case Study: COVID-19 Pandemic}

Preventing the spread of infectious disease would reduce the overall need for antibiotics, thereby reducing antibiotic over-prescription and misuse. During the COVID-19 pandemic infection prevention measures, such as mask mandates, emphasizing hand washing, disinfection, and social distancing, were put in place to prevent the spread of SARS-CoV-2 [206,207]. These precautions resulted in an overall reduction in community spread of other respiratory diseases during the 2020 season in comparison to 2019, including influenza ( $17.4 \%$ decrease), enterovirus (51.6\% decrease), and all-cause pneumonia (18.8\% decrease) [207]. Despite the additional training of medical staff on infection control measures, there was no decrease in nosocomial infection rates. One example of this is carbapenem-resistant Enterobacteriaceae (CRE); in 2019 the infection rate of CRE in ICUs was $6.7 \%$, but by April 2020 the rate was at $50 \%$ [208]. This demonstrates that even in the hyper-aware environment of a global pandemic serious bacterial infections are still prevalent and have the potential to grow in number affected. It should also be noted that funding and publishing research on infectious diseases other than COVID-19 during this 
time has been significantly reduced and will have serious impacts on the future of the field (reviewed in [209-212]).

\section{The Case for Anti-Virulence Therapeutics}

Traditional antibiotics work by disrupting essential cellular functions of bacteria. A major downside to this approach is that these cellular functions are widely conserved and present in both pathogenic and commensal bacteria. In contrast, anti-virulence therapies target mechanisms in bacteria that are essential for pathogenesis but are not essential for cell viability [144,213]. A major difference between antibiotics and anti-virulence therapies is that the latter does not directly cause selective pressure. This should, in theory, reduce the rate at which resistance to anti-virulence therapies occurs [145]. Collectively, anti-virulence therapies allow the host's natural immune response to eliminate the pathogen rather than killing a pathogen outright [214-217]. A major advantage to this approach is that bacterial SOS responses have yet to be implicated as a result of treatment [218].

The bacterial type III secretion system (T3SS) is a virulence factor used by most pathogenic Gram-negative bacteria to cause infection by injecting virulence proteins, called effectors, that reprogram the host cell machinery and allow evasion of the host immune response. The T3SS is absent from commensal bacteria and as such, any therapies targeting it should not affect commensal bacteria [15]. Some virulence factors, like the T3SS, are regulated by quorum sensing (QS), a grouping of pathways that regulate gene expression in a concentration-dependent manner. QS is used by both pathogenic and commensal bacteria. Compounds inhibiting QS may not be lethal to bacteria but could prevent colonization and infection by reducing the infectivity of pathogens. In recent years, the use of liposomes has emerged as an anti-infective strategy for treating infections caused by pathogenic Gram-positive bacteria. This strategy is not limited to one specific pathogenesis pathway, and the merits of this approach will be discussed in this section. These examples will be used to demonstrate the potential of direct ani-virulence targets (T3SS), anti-virulence signaling targets (QS), and indirect anti-virulence strategies (liposomes).

\subsection{The Bacterial Type III Secretion System (T3SS)}

The type III secretion system (T3SS) is used by many pathogenic Gram-negative bacteria to cause and maintain an infection. Pathogens using a T3SS include Chlamydia trachomatis, Escherichia coli, Pseudomonas aeruginosa, Salmonella enterica, Shigella spp., Vibrio cholerae, and Yersinia pestis [219,220]. The T3SS is highly conserved between bacterial pathogens of a particular genus [221]. This conservation can result in high recognition amongst different species or serovars of bacteria. The T3SS is a syringe-like apparatus that translocates effector proteins directly into a host cell [220,222]. These effectors hijack the host cell machinery to allow for colonization and to subvert the host immune response. These mechanisms include interference with actin and tubulin, gene expression, cell cycle progression, or induce programmed cell death in their host [223]. Bacteria with a nonfunctional T3SS have attenuated virulence but are still capable of growth, making them a perfect target for anti-virulence therapeutics [222]. This also lends to the theory that T3SS inhibition will reduce selective pressure on the pathogen, resulting in slower resistance formation to T3SS inhibitors [219]. The T3SS is specific to pathogens, meaning any interventions targeting it should not affect commensal bacteria [224]. Although no T3SS inhibitors have been FDA approved, the T3SS is one of the most validated anti-virulence targets, with many compounds in development (Table 1) [225]. 
Table 1. Select anti-T3SS therapies in development.

\begin{tabular}{|c|c|c|c|}
\hline Anti-Virulence Compound & Mode of Action & Bacteria & Stage \\
\hline Aurodox [226-228] & $\begin{array}{l}\text { Downregulation of } \\
\text { T3SS-related genes }\end{array}$ & EPEC and EHEC & Animal Models \\
\hline Compound D [14] & Secretion blockade & Yersinia and Pseudomonas spp. & In Vitro \\
\hline Compounds 7146 and 1504 [14] & ATPase inhibition & Yersinia and Burkholderia spp. & In Vitro \\
\hline INP175 [14] & ATPase inhibition & $\begin{array}{l}\text { P. aeruginosa, Y. } \\
\text { pseudotuberculosis, and C. } \\
\text { trachomatis }\end{array}$ & In Vitro \\
\hline MBX 23 [14] & Needle subunit inhibition & $\begin{array}{l}\text { Pseudomonas, Chlamydia, and } \\
\text { Yersinia spp. }\end{array}$ & Animal Models \\
\hline $\begin{array}{l}\text { Anti-PcrV monoclonal antibody } \\
\text { (MEDI3902) [14] }\end{array}$ & Needle tip inhibition & P. aeruginosa & Clinical Trials [229-231] \\
\hline $\begin{array}{l}\text { Salicylidene acylhydrazides } \\
\text { (e.g., MED055, RCZ12, and } \\
\text { INP040, etc.) [14] }\end{array}$ & T3SS formation inhibition & $\begin{array}{l}\text { Yersinia, Chlamydia, Salmonella, } \\
\text { Shigella, EHEC, Xanthomonas, } \\
\text { and Erwinia spp. }\end{array}$ & Animal Models \\
\hline Thymol [232] & Translocation inhibition & Salmonella spp. & Animal Models \\
\hline Anti-Tir antibody (TD4) [14] & Adhesion inhibition & EPEC and EHEC & Animal Models \\
\hline $\begin{array}{l}\text { 2-imino-5-arylidene } \\
\text { thiazolidinone [14] }\end{array}$ & $\begin{array}{l}\text { Basal body alkaline } \\
\text { phosphatase inhibition }\end{array}$ & $\begin{array}{l}\text { Salmonella, Pseudomonas, and } \\
\text { Yersinia spp. }\end{array}$ & In Vitro \\
\hline $12(4,6)$ and $12(6,4)[14]$ & $\begin{array}{l}\text { Needle subunit } \\
\text { chaperone inhibition }\end{array}$ & Pseudomonas spp. & Animal Models \\
\hline
\end{tabular}

Small molecule inhibitors of the T3SS have been shown to increase survival rates after infection with otherwise lethal doses of the bacterial pathogen (Table 1) [14,232] McHugh et al. showed the ability of the natural product aurodox to decrease effector protein secretion and decrease the infectious potential of enterohemorrhagic E. coli (EHEC). Transcriptomal analysis of genes affected by aurodox showed downregulation of 25 of the 41 genes related to the T3SS, including ler, a major activator of the T3SS [228]. This suggests aurodox acts as a gene repressor and not by directly binding to T3SS, although the true mode of action is still unknown. Aurodox was shown to prevent T3SS mediated hemolysis, with an $\mathrm{ID}_{50}$ of $1.5 \mu \mathrm{g} / \mathrm{mL}$ (Figure 6A) [227,228]. Kimura et al. collected further data to analyze the effectiveness of aurodox on alleviating T3SS-mediated infection using an in vivo mouse model [226]. Mice were infected with Citrobacter rodentium, a murine variant of enteropathogenic E. coli (EPEC), and then either treated with 10\% DMSO as a control, a single dose of tetracycline $(200 \mathrm{mg} / \mathrm{kg})$, or aurodox $(25 \mathrm{mg} / \mathrm{kg})$ every $24 \mathrm{~h}$ for four days. All mice treated with aurodox or a functional T3SS knockout strain survived, while those treated with tetracycline did not (Figure 6C). In addition, treatment with aurodox does not induce Shiga toxin production in EHEC, suggesting promise for the use of T3SS inhibitors to treat infection [218].

Therapeutics targeting the needle tip protein of the T3SS have gone into clinical trials. One of these, termed KB001-A, is a human PEGylated IgG monoclonal anti-PcrV Fab that is proposed to form a secretion blockade mechanism of pathogenesis prevention for $P$. aeruginosa [233-239]. KB001-A has undergone phase I and II clinical trials for both ventilatorassociated P. aeruginosa and treatment of chronic pneumonia in cystic fibrosis patients but did not advance to phase III trials due to a lack of efficacy $[235,236,240]$. More recently MEDI3902, another anti-PcrV mAb, has entered human clinical trials. This bispecific antibody targets both PcrV and Psl exopolysaccharide, an anti-biofilm formation target. MEDI3902 was shown to dose-dependently increase survival, reduce lung inflammation, and decrease bacterial loads in both rabbit and mouse P. aeruginosa challenge models [241]. Le et al. showed MEDI3902 was effective as a treatment and a prophylactic for acute blood and acute lung P. aeruginosa infections [242]. MEDI3902 performed well in phase I clinical trials in the US $[229,230]$. Although a single dose of MEDI3902 was shown to provide good pharmacokinetics and pharmacodynamics in phase II trials, it did not achieve primary efficacy [231]. The results from anti-T3SS therapies are promising and these examples are just the beginning. 
(A)

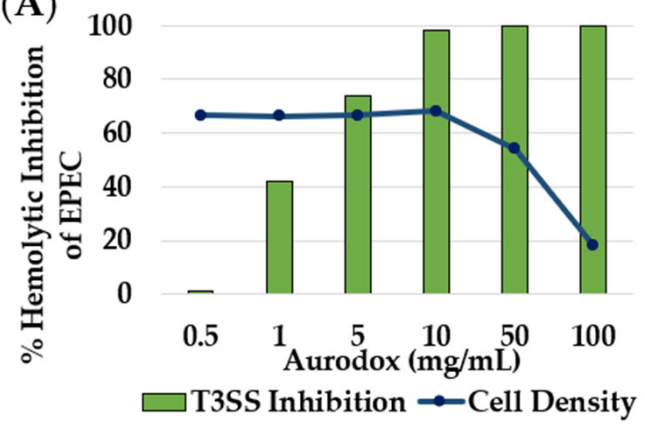

(B)

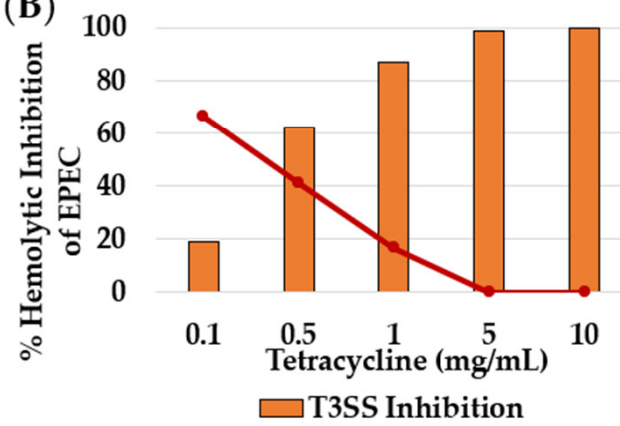

(C)

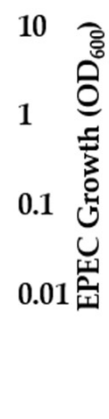

10

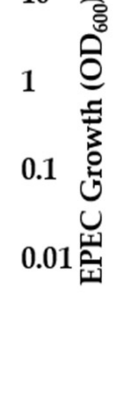

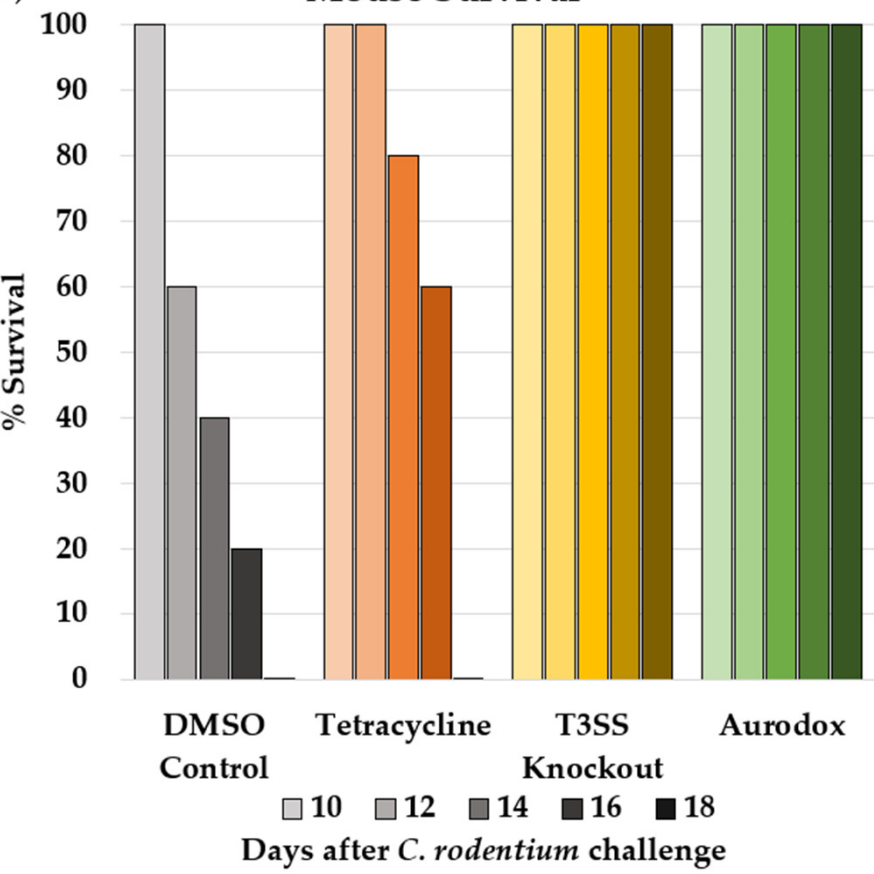

Figure 6. In vitro and in vivo activity of T3SS inhibitor aurodox. (A) Concentration of up to $10 \mathrm{mg} / \mathrm{mL}$ aurodox dosedependently inhibit the T3SS without effecting cell growth; (B) The decrease in hemolytic activity is due to tetracycline killing bacteria; (C) 100\% of mice given aurodox survived to day 18 after infection, while none treated with tetracycline survived. Data from [226].

\subsection{Quorum Sensing}

Quorum sensing (QS) is the process used by bacteria to control gene expression in response to cell density and external factors sensing [16-18]. Small molecules, called autoinducers, are produced by bacteria and release to be sensed by other bacteria. These allow a bacterial population to sense neighboring cells sensing [16-18]. QS is used to control a variety of critical functions related to growth, colonization, and pathogenesis. These including biofilm formation, virulence factor deployment, and antibiotic resistance gene expression [243]. Inhibition of QS could prevent pathogenic bacteria from coordinating virulence factor usage sensing [16-18]. This could reduce the pathogen's infectivity, allowing the host immune system to clear the infection more effectively. QS inhibition could also increase the efficacy of existing antibiotics by virtue of inhibiting antibiotic resistance gene expression sensing [16-18]. This could allow existing antibiotics to have increased time as first-line therapies. The use of QS inhibitors as anti-virulence therapeutics is a growing field with many promising compounds (Table 2).

There are many different interconnected mechanisms controlled by QS, so a highly simplified explanation of the moderately well described QS pathways of Pseudomonas spp. will be used as an example [16,243]. In this section we discuss two groups of signaling molecules, quinolones and acyl-homoserine lactones (AHLs), that control three pathways of the Pseudomonas QS system: Pseudomonas quinolone signal (PQS), las signaling, and rhl signaling. PQS is induced by quinolone accumulation and results in increased cell-cell signaling, virulence protein expression (e.g., the T3SS), iron acquisition, oxidative stress, antioxidative response, and modulation of host immune responses. AHLs induce both las and rhl signaling. las upregulates both PQS and rhl QS pathways, as well as biofilm formation and other virulence factors. $r h l$ signaling induces the production of toxins such as rhamnolipids, pyocyanin, and hydrogen cyanide [243]. These pathways are all interconnected in a highly complex manner that has been left out of this review for brevity. More in-depth reviews of QS systems, including Pseudomonas QS, are referenced in Table 2. 
Table 2. Select anti-QS therapies in development.

\begin{tabular}{|c|c|c|c|}
\hline Anti-Virulence Compound & Mode of Action & Bacterium (QS Pathway Reviews) & Stage \\
\hline Azithromycin [244] & Decrease QS gene expression & Pseudomonas spp. [245] & Clinical Trials \\
\hline $\begin{array}{l}\text { Furanone derivatives } \\
\text { (e.g., C-30) [220] }\end{array}$ & las inhibition & Pseudomonas spp. [245] & In Vitro \\
\hline Coumarin [246] & Decrease QS gene expression & $\begin{array}{l}\text { E. coli [247], P. aeruginosa [245], S. } \\
\text { aureus [248], and Vibrio spp. [249] }\end{array}$ & In Vitro \\
\hline Cyclic dipeptides $[250,251]$ & Indicated in reporter assays & $\begin{array}{l}\text { E. coli [247], P. aeruginosa [245], and } \\
\text { Vibrio spp. [249] }\end{array}$ & In Vitro \\
\hline DPD derivatives [17] & LrsK inhibition & Salmonella spp. [252] & In Vitro \\
\hline $\begin{array}{l}\text { Epigallocatechin-3- } \\
\text { gallate }[253,254]\end{array}$ & Decrease QS gene expression & $\begin{array}{l}\text { EHEC [247], Pseudomonas [245], } \\
\text { Salmonella [252], and Staphylococcus } \\
\text { spp. [248] }\end{array}$ & In Vitro \\
\hline Hamamelitannin [255] & $\begin{array}{l}\text { Peptidoglycan biosynthesis } \\
\text { and eDNA release inhibition }\end{array}$ & Staphylococcus spp. [248] & Animal Models \\
\hline LED209 [256] & QseC inhibition & EHEC [247] and Salmonella spp. [252] & Animal Models \\
\hline Sinefungin [257] & Inhibition of AI-2 Synthesis & Streptococcus spp. [258] & Animal Models \\
\hline
\end{tabular}

One of the many natural products identified with QS inhibitory activity is coumarin, the parent compound of a class of plant phenolics. Coumarin was shown to decrease the expression of multiple QS genes in P. aeruginosa strain PA14, including $p q s A$ and rhlI, as well as decrease virulence phenotypes such as swarming motility and phenazine production [246]. Coumarin was found to inhibit PA14 biofilm formation, a mechanism mainly controlled through las signaling [246]. This indicated coumarin had a role in all three major Pseudomonas QS pathways. The biofilm inhibitory capabilities of coumarin was shown in other Gram-negative and Gram-positive bacteria, including E. coli, Edwardsiella tarda, Vibrio anguillarum, and S. aureus, thus showing the broad spectrum of anti-QS activity of coumarin [246,259].

Approximately $65 \%$ of infections are caused by biofilm-forming bacteria [260], and these biofilms are regulated by QS [261]. Biofilms are an immobile community of bacteria living on a surface that share resources within an extracellular matrix [261]. Biofilms protect from sudden changes in $\mathrm{pH}$, osmolarity, nutrients scarcity, mechanical, and shear forces [262,263]. They also prevent antibiotics and host immune cells from accessing bacteria within the biofilm community [264,265]. Methods for the inhibition of biofilms include deploying compounds that disrupt or remove established biofilms and the use of antibiotics, antimicrobials, or antibiofilm compounds on a matrix to disrupt biofilm formation [260].

Furanone A, a natural product isolated from the algae Delisea pulchra, has been shown to inhibit QS through las modulation. A derivative of Furanone A, named C-30, was found to interfere with biofilm formation in both planktonic cultures and established biofilm colonies of P. aeruginosa [220]. It was later shown to have synergistic effects when combined with an antibiotic, increasing the effectiveness of the antibiotic tobramycin, despite having no antibiotic activity itself. Although not quantified, qualitative data of colonies treated with the combination showed a drastic decrease in biofilm matrix and increase in cell death by two to three magnitudes, with only $5-10 \%$ of cells remaining alive after treatment [220]. This was due to the antibiofilm activity of C-30 which allowed tobramycin to reach the bacteria more easily. It also likely contributed to a decrease in antibiotic resistance gene expression, thereby increasing the efficacy of tobramycin. This example sets the precedent that anti-biofilm and/or anti-QS compounds can be used in conjunction with known antibiotics to increase their efficacy and lifespan as therapeutics.

\subsection{Liposomes}

Liposomes are cell-like vesicles formed by an agglomerate of phospholipids. Phospholipids are amphipathic due to a hydrophobic "tail" and a hydrophilic "head" (Figure 7) [19-21]. Because of this, they can spontaneously form liposomes when placed into polar, typically aqueous, media. The phospholipids arrange into a bilayer, like a cell membrane, enclosing 
a sphere of the media (Figure 7) [266]. Liposomes can be synthesized in a laboratory using a variety of lipids, cholesterol, and lipoproteins, making them highly customizable [267]. Liposomes have applications in many different fields: cosmetics, medical imaging, vaccination, and drug delivery [268].

(A) Hydrophilic "heads"

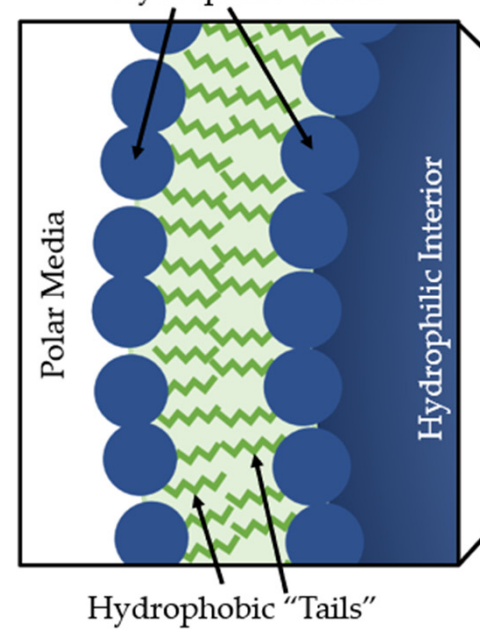

(B)

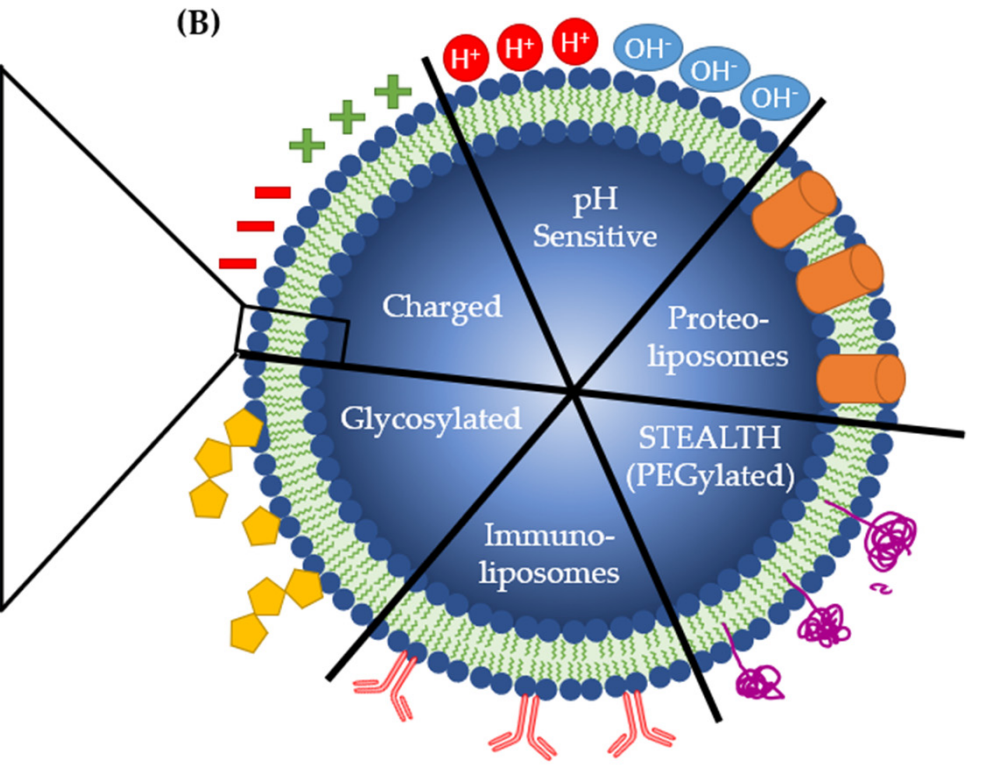

Figure 7. Structure and type of liposomes. (A) Liposomes are composed of phospholipids containing hydrophilic "heads" and hydrophobic "tails" that organize into micelles. Within the micelle is a hydrophilic interior while the exterior is polar media; (B) Modifications to liposomes can greatly enhance the ability of liposomes to localize to a desired target. This includes incorporating charged or $\mathrm{pH}$-sensitive moieties, $\mathrm{PEG}$, or carbohydrate components into the phospholipid bilayer or coating liposomes with proteins or immunoglobulin.

The use of liposomes can increase the local concentration of drugs at the therapeutic site. This can improve the efficiency of therapies while simultaneously decreasing off-target toxicity. Liposomes can also improve the pharmacokinetics and biodistribution of a delivered drug, enhancing drug absorption to increase plasma concentration, and increasing the half-life of drugs $[269,270]$. Variations in the type and proportions of components used to form liposomes, as well as the method used to form them, can give them a range of $\mathrm{pH}$ sensitivities, sizes, number of bilayers (called lamellae), temperature sensitivities, and membrane fluidities [267]. Because of their customizable nature, liposomes have been used for delivering antifungals [271,272], antineoplastics [269,273-275], antibiotics [276,277], and even gene- or drug-therapies for Alzheimer's disease [278,279].

Because liposomes can target a specific area, they can allow for lower toxicity than their free-drug counterparts $[269,271,272,275,280]$. Bakker-Woudenberg et al. showed free ciprofloxacin can cause toxicity at a concentration of $40 \mathrm{mg} / \mathrm{kg} /$ dose but is tolerated to $160 \mathrm{mg} / \mathrm{kg} /$ dose when delivered with liposomes [280]. Liposomes can also increase the general activity of the drug they carry $[277,280]$. For example, using cationic liposomes to deliver clarithromycin reduced the minimum bactericidal concentration (MBC) of clarithromycin to $16 \mathrm{mg} / \mathrm{L}$ against several highly resistant clinical strains of $P$. aeruginosa, compared with $512 \mathrm{mg} / \mathrm{L}$ for free drug and $64 \mathrm{mg} / \mathrm{L}$ for anionic liposomes alone [277].

More recently, liposomes have been designed for anti-virulence therapies [281]. Grampositive bacteria, such as Staphylococcus spp. and Streptococcus spp., interact with eukaryotic host cells to deliver virulence factors across the cell membrane [282] or release toxins into the surrounding media [283]. Liposomes can be designed as eukaryotic host cell mimics that act as bait for pathogens or as toxin scavengers. This can result in pathogens. To unproductively use their virulence factors and resources on the liposome instead of eukaryotic host cells. This ultimately lowers the infectivity of the pathogen, which in turn increases the minimum infectious dose required to cause infection. Equally important is 
that anti-virulent liposomes have broad-spectrum pathogenesis-hindering activity. An anti-virulent liposome injection was able to save mice from an otherwise lethal dose of S. pneumoniae or S. aureus if given, at most, $10 \mathrm{~h}$ after infection [281]. This means one formulation of liposomes could be used to treat a variety of infections similarly to broadspectrum antibiotics but without the harmful side effects.

Many bacterial toxins bind to membrane components that are host-specific, such as cholesterol (Ch), phosphatidylcholine (PC), or sphingomyelin (Sm) [281]. Pathogenreleased pore-forming toxins such as streptolysin O (SLO) bind to Ch or PC and then self-associate with other SLO monomers to form a ring- or arc-shaped complex that creates lesions in the host cell membrane, reducing the integrity of host cells [284]. Liposomes containing large proportions of the pathogen-targeted membrane components can be more attractive for toxins than a real cell. Henry et al. found that toxin-sequestering liposomes are effective in vivo by reducing bacterial load in the blood and lungs and doubling the survival rate of mice intranasally infected by S. pneumoniae (Figure 8A) [281].

(A) Intranasal delivery of S. pneumoniae and liposomes to mice

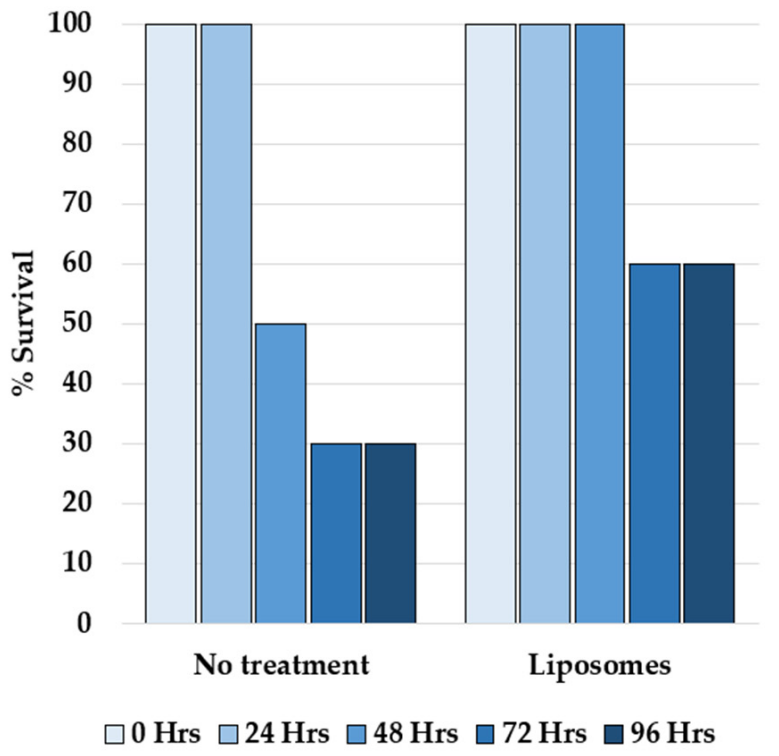

(B) Intravenous delivery of $S$. aureus and liposomes to mice (additional doses at 6, $24 \mathrm{hrs)}$

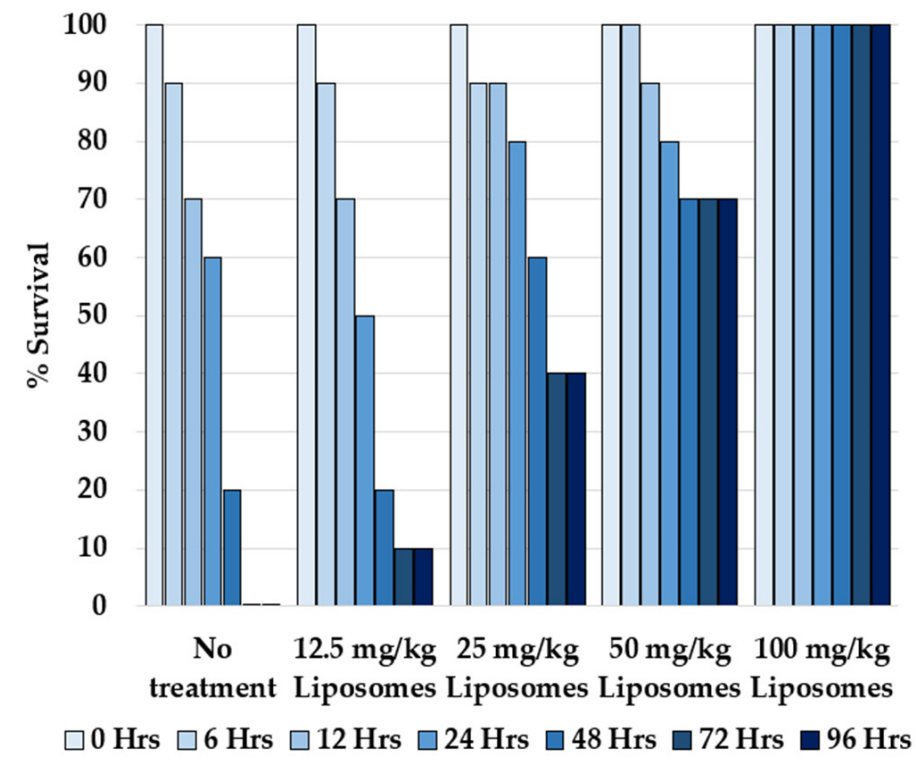

Figure 8. Treatment of S. pneumoniae and MRSA with liposomes. (A) Treatment with $100 \mathrm{mg} / \mathrm{kg}$ of a 1:1:1:1 mixture of Ch:Sm $(66 \mathrm{~mol} \% \mathrm{Ch})+\mathrm{Ch}: \mathrm{PC}(66 \mathrm{~mol} \% \mathrm{Ch})+\mathrm{Sm}+\mathrm{Sm}: \mathrm{PC}(75 \mathrm{~mol} \% \mathrm{Sm})$ liposomes was able to double the survival rate of mice infected with S. pneumoniae. (B) Liposomes dose-dependently increase the survival rate of mice infected with MRSA, with $100 \mathrm{mg} / \mathrm{kg}$ and higher concentrations of a 1:1 mixture of Ch:Sm + Sm liposomes resulting in 100\% survival.

Liposomal cholesterol is a key target for many pathogens. Liposomes composed of the largest proportion of $\mathrm{Ch}$ possible $(66 \mathrm{~mol} \%)$ along with either PC or Sm were the most effective for neutralizing an array of toxins [281]. In some instances, however, a combination of differently formulated liposomes may be required for maximum neutralization of toxins. Henry et al. showed that liposomes composed of $\mathrm{Ch}: \mathrm{Sm}$ or $\mathrm{Ch}: \mathrm{PC}$ protected monocytes in vitro from MRSA only partially, whereas a combination of both Ch:PC and Sm liposomes led to $100 \%$ survival of the monocytes (Figure 8B) [281]. This suggests that MRSA secretes at least two toxins: one that is neutralized by $\mathrm{Ch}: \mathrm{PC}$ liposomes and one that is neutralized by Sm liposomes.

Using liposomes to prevent toxins from damaging cells has the secondary benefit of preventing the cytokine storm and septic shock associated with an inflammatory response [281]. This is a major advantage of anti-virulence liposomes over antibiotics; pathogen lysis by antibiotics can cause a very sudden release of toxins and strongly activate the destructive inflammatory response whereas liposomes sequester the pathogen or 
toxins [285]. For example, the pathogen S. pneumoniae carries endotoxins that are released only when the cell is lysed [286]. This toxin flood release may be counteracted by combination therapy of liposomes and antibiotics, which was shown to increase host survival chances beyond that of antibiotics alone, as liposomes can neutralize the toxins released by bactericidal agents [281].

\subsection{Combination Therapies}

One disadvantage of using anti-virulence therapies is that by design they do not actively clear infectious bacteria from a patient. This can be problematic for patients who are immunocompromised, either naturally or through the severity of infection. Notwithstanding the potential lack of efficacy, these therapies could be used in combination with traditional antibiotics to reduce the adverse effects of using antibiotics alone. These combination therapies may also allow for reduced drug dosages and treatment duration, leading to reduced resistance formation and side effects [73].

Evidence of this synergistic approach was demonstrated by Secher et al. in a study of an anti-P. aeruginosa mAb targeting the needle tip of the T3SS with the broad-spectrum antibiotic meropenem. An additive effect was observed when the combination was given to patients. Meropenem-resistant infections had similar efficacy to treatments with the $\mathrm{mAb}$ alone against meropenem-sensitive infections, showing an ability of combination therapy to overcome drug resistance [287]. Le et al. demonstrated that MEDI3902, another anti- $P$. aeruginosa $\mathrm{mAb}$ targeting the T3SS, showed enhanced activity against $P$. aeruginosa infections when administered in combination with a subtherapeutic dose of meropenem [241]. Anti-T3SS mAb therapy had increased effectivity when administered in combination therapy with either ciprofloxacin, tobramycin, and ceftazidime against acute $P$. aeruginosa infection [288]. These results show that regardless of their success as individual agents, anti-virulence therapeutics can also be employed in combination with antibiotics to reduce the overall downsides to antibiotic use by reducing doses and time of treatment.

\section{Conclusions}

The use of antibiotic therapies for the treatment of bacterial infections has been indispensable during the rise of modern medicine. However, their use does not come without significant downsides. Anti-microbial resistance gene formation and proliferation is the most notorious of these and has rendered many antibiotic agents ineffective. Many antibiotics reduce the ability of patients to fight infection after treatment due to the loss of commensals. Antibiotics may also cause the induction of bacterial SOS responses that can result in the release of toxins which lead to serious side effects. To mediate these downsides, clinicians have tried to implement multiple mediation methods or alternative care plans. These include the use of combination therapies, point of care testing, narrowspectrum treatments, antibiotic stewardship programs, and increased infection control. Unfortunately, these mediation methods serve only to reduce and slow the problem, not eradicate the cause.

Anti-virulence therapies have been proposed as one solution to the downsides of antibiotic use. Anti-virulence agents do not directly cause bacterial cell death, instead, they target mechanisms used by pathogens to cause infection and evade the host immune response. These agents exhibit reduced selective pressure compared to traditional antibiotics, thereby mitigating resistance formation. In contrast to antibiotics, anti-virulence therapies do not affect commensal bacteria that protect against secondary infections. Additionally, anti-virulence agents do not induce bacterial SOS-responses that are often responsible for severe side effects associated with antibiotic treatment. We have described three groups of promising anti-virulence targets and therapies: the T3SS, quorum sensing, and liposomes. These therapies have successfully demonstrated the potential for development into bacterial infection treatments either alone or in combination with antibiotics. 
Author Contributions: Conceptualization, A.E.M.; writing-original draft preparation, J.A.H., S.T.M. and A.E.M.; writing-review and editing, J.A.H. and A.E.M. All authors have read and agreed to the published version of the manuscript.

Funding: This research was funded by startup funds from the School of Pharmacy at Virginia Commonwealth University (VCU). This work was also supported by VCU's CTSA (UL1TR002649 from the National Center for Advancing Translational Sciences) and the CCTR Endowment Fund of Virginia Commonwealth University.

Conflicts of Interest: The authors declare no conflict of interest.

\section{References}

1. Fleming, A. On the antibacterial action of cultures of a Penicillium, with special reference to their use in the isolation of $B$. injluenzae. Br. J. Exp. Pathol. 1929, 10, 226-236. [CrossRef]

2. Centers for Disease Control and Prevention. National Notifiable Diseases Surveillance System, 2019 Annual Tables of Infectious Disease Data. Atlanta, GA, USA, 2021. Available online: https://wonder.cdc.gov/nndss/nndss_annual_tables_menu.asp (accessed on 8 August 2021).

3. Dion, C.F.; Ashurst, J.V. Pneumonia, Streptococcus pneumonia; StatPearls Publishing: Treasurer Island, FL, USA, 2018. Available online: https: / / www.ncbi.nlm.nih.gov/books/NBK470537/ (accessed on 18 August 2021).

4. World Health Organization. Antimicrobial Resistance: Global Report on Surveillance; WHO Press: Geneva, Switzerland, 2014; Volume 61, pp. 383-394.

5. Smith, R.A.; M'ikanatha, N.M.; Read, A.F. Antibiotic resistance: A primer and call to action. Health Commun. 2015, 30, 309-314. [CrossRef]

6. US Department of Health and Human Services; CDC. Antibiotic Resistance Threats in the United States. Available online: https://www.cdc.gov/drugresistance/biggest_threats.html (accessed on 8 August 2021).

7. Infectious Diseases Society of America. Bad bugs, no drugs: As antibiotic discovery stagnates...a public health crisis brews. Infect. Dis. Soc. Am. 2004, 35, 14-15.

8. Roubaud-Baudron, C.; Ruiz, V.E.; Swan, A.M.; Vallance, B.A.; Ozkul, C.; Pei, Z.; Li, J.; Battaglia, T.W.; Perez-Perez, G.I.; Blaser, M.J. Long-term effects of early-life antibiotic exposure on resistance to subsequent bacterial infection. mBio 2019, 10, e02820. [CrossRef] [PubMed]

9. Iacovelli, V.; Gaziev, G.; Topazio, L.; Bove, P.; Vespasiani, G.; Finazzi Agrò, E. Nosocomial urinary tract infections: A review. Urologia 2014, 81, 222-227. [CrossRef] [PubMed]

10. McFarland, L.V. Epidemiology, risk factors and treatments for antibiotic-associated diarrhea. Dig. Dis. 1998, 16, 292-307. [CrossRef]

11. Dubnau, D.; Blokesch, M. Mechanisms of DNA uptake by naturally competent bacteria. Annu. Rev. Genet. 2019, 53, 217-237. [CrossRef]

12. Beaber, J.W.; Hochhut, B.; Waldor, M.K. SOS response promotes horizontal dissemination of antibiotic resistance genes. Nature 2004, 427, 72-74. [CrossRef]

13. Kline, T.; Felise, H.B.; Sanowar, S.; Miller, S.I. The type III secretion system as a source of novel antibacterial drug targets. Curr. Drug Targets 2012, 13, 338-351. [CrossRef]

14. Hotinger, J.A.; Pendergrass, H.A.; May, A.E. Molecular targets and strategies for inhibition of the bacterial type III secretion system (T3SS); Inhibitors directly binding to T3SS components. Biomolecules 2021, 11, 316. [CrossRef]

15. Hauser, A.R.; Mecsas, J.; Moir, D.T. Beyond antibiotics: New therapeutic approaches for bacterial infections. Clin. Infect. Dis. 2016, 63, 89-95. [CrossRef]

16. Bru, J.L.; Rawson, B.; Trinh, C.; Whiteson, K.; Høyland-Kroghsbo, N.M.; Siryaporn, A. PQS produced by the Pseudomonas aeruginosa stress response repels swarms away from bacteriophage and antibiotics. J. Bacteriol. 2019, 201, e00383-19. [CrossRef] [PubMed]

17. Linciano, P.; Cavalloro, V.; Martino, E.; Kirchmair, J.; Listro, R.; Rossi, D.; Collina, S. Tackling antimicrobial resistance with small molecules targeting LsrK: Challenges and opportunities. J. Med. Chem. 2020, 63, 15243-15257. [CrossRef] [PubMed]

18. Vikram, A.; Jayaprakasha, G.K.; Jesudhasan, P.R.; Pillai, S.D.; Patil, B.S. Suppression of bacterial cell-cell signaling, biofilm formation and type III secretion system by citrus flavonoids. J. Appl. Microbiol. 2010, 109, 515-527. [CrossRef] [PubMed]

19. Chirgwin, M.E.; Dedloff, M.R.; Holban, A.M.; Gestal, M.C. Novel therapeutic strategies applied to Pseudomonas aeruginosa infections in Cystic fibrosis. Materials 2019, 12, 4093. [CrossRef] [PubMed]

20. Shirley, M. Amikacin liposome inhalation suspension: A review in Mycobacterium avium complex lung disease. Drugs 2019, 79, 555-562. [CrossRef]

21. Kheirolomoom, A.; Ferrara, K.W. Cholesterol transport from liposomal delivery vehicles. Biomaterials 2007, 28, 4311-4320. [CrossRef]

22. Centers for Disease Control and Prevention; National Centre for Health Statistics. Expectancy. Available online: https://www. cdc.gov/nchs/fastats/life-expectancy.htm (accessed on 8 August 2021). 
23. Centers for Disease Control and Prevention. National Center for Health Statistics National Vital Statistics Reports; Centers for Disease Control and Prevention: Hyattsville, MD, USA, 2021; Volume 69. Available online: https://www.cdc.gov/nchs/products/nvsr.htm (accessed on 8 August 2021).

24. D'costa, V.M.; King, C.E.; Kalan, L.; Morar, M.; Sung, W.W.L.; Schwarz, C.; Froese, D.; Zazula, G.; Calmels, F.; Debruyne, R.; et al. Antibiotic resistance is ancient. Nature 2011, 477, 457-461. [CrossRef]

25. Scott, L.C.; Lee, N.; Aw, T.G. Antibiotic resistance in minimally human-impacted environments. Int. J. Environ. Res. Public Health 2020, 17, 3939. [CrossRef]

26. Bilton, D.; Pressler, T.; Fajac, I.; Clancy, J.P.; Sands, D.; Minic, P.; Cipolli, M.; Galeva, I.; Solé, A.; Quittner, A.L.; et al. Amikacin liposome inhalation suspension for chronic Pseudomonas aeruginosa infection in cystic fibrosis. J. Cyst. Fibros. 2020, $19,284-291$. [CrossRef] [PubMed]

27. Ruiz, J.; Mensa, L.; Pons, M.J.; Vila, J.; Gascon, J. Development of Escherichia coli rifaximin-resistant mutants: Frequency of selection and stability. J. Antimicrob. Chemother. 2008, 61, 1016-1019. [CrossRef]

28. Perry, J.; Waglechner, N.; Wright, G. The prehistory of antibiotic resistance. Cold Spring Harb. Perspect. Med. 2016, 6, a025197. [CrossRef]

29. Davies, J.; Davies, D. Origins and evolution of antibiotic resistance. Microbiol. Mol. Biol. Rev. 2010, 74, 417-433. [CrossRef]

30. O'Neill, J. Antimicrobial resistance: Tackling a crisis for the health and wealth of nations. Rev. Antimicrob. Resist. 2014. Available online: https:/ / www.jpiamr.eu/wp-content/uploads/2014/12/AMR-Review-Paper-Tackling-a-crisis-for-the-healthand-wealth-of-nations_1-2.pdf (accessed on 8 August 2021).

31. Carlet, J. The gut is the epicentre of antibiotic resistance. Antimicrob. Resist. Infect. Control 2012, 1, 39. [CrossRef] [PubMed]

32. Sommer, M.O.A.; Church, G.M.; Dantas, G. The human microbiome harbors a diverse reservoir of antibiotic resistance genes. Virulence 2010, 1, 299-303. [CrossRef] [PubMed]

33. Moyaert, H.; Morrissey, I.; De Jong, A.; El Garch, F.; Klein, U.; Ludwig, C.; Thiry, J.; Youala, M. Antimicrobial susceptibility monitoring of bacterial pathogens isolated from urinary tract infections in dogs and cats across Europe: ComPath results. Microb. Drug Resist. 2017, 23, 391-403. [CrossRef] [PubMed]

34. Marques, C.; Belas, A.; Franco, A.; Aboim, C.; Gama, L.T.; Pomba, C. Increase in antimicrobial resistance and emergence of major international high-risk clonal lineages in dogs and cats with urinary tract infection: 16 year retrospective study. J. Antimicrob. Chemother. 2018, 73, 377-384. [CrossRef] [PubMed]

35. Vilte, D.A.; Larzábal, M.; Garbaccio, S.; Gammella, M.; Rabinovitz, B.C.; Elizondo, A.M.; Cantet, R.J.C.; Delgado, F.; Meikle, V.; Cataldi, A.; et al. Reduced faecal shedding of Escherichia coli O157:H7 in cattle following systemic vaccination with $\gamma$-intimin C280 and EspB proteins. Vaccine 2011, 29, 3962-3968. [CrossRef] [PubMed]

36. Czepiel, C.; Dróżdż, M.; Pituch, H.; Kuijper, E.J.; Perucki, W.; Mielimonka, A.; Goldman, S.; Wultańska, D.; Garlicki, A.; Biesiada, G. Clostridium difficile infection: Review. Eur. J. Clin. Microbiol. Infect. Dis. 2019, 38, 1211-1221. [CrossRef]

37. Merda, D.; Briand, M.; Bosis, E.; Rousseau, C.; Portier, P.; Barret, M.; Jacques, M.A.; Fischer-Le Saux, M. Ancestral acquisitions, gene flow and multiple evolutionary trajectories of the type three secretion system and effectors in Xanthomonas plant pathogens. Mol. Ecol. 2017, 26, 5939-5952. [CrossRef]

38. Mathews, K. Antimicrobial drug use and veterinary costs in US livestock production. USDA Agric. Inf. Bull. 2001, 766. Available online: https:/ / www.ers.usda.gov/webdocs/publications/42375/17768_aib766_1_.pdf?v=0 (accessed on 27 August 2021).

39. Hiltunen, T.; Virta, M.; Anna-Liisa, L. Antibiotic resistance in the wild: An eco-evolutionary perspective. Philos. Trans. R. Soc. B Biol. Sci. 2017, 372, 20160039. [CrossRef]

40. Donnenberg, M.S.; Tzipori, S.; Mckee, M.L.; O'brien, A.D.; Alroy, J.; Kapert, J.B. The role of the eae gene of enterohemorrhagic Escherichia coli in intimate attachment in vitro and in a porcine model bacterial adhesion. Clin. Investig. 1993, 92, 1418-1424. [CrossRef]

41. Rabinovitz, B.C.; Gerhardt, E.; Tironi Farinati, C.; Abdala, A.; Galarza, R.; Vilte, D.A.; Ibarra, C.; Cataldi, A.; Mercado, E.C. Vaccination of pregnant cows with EspA, EspB, $\gamma$-intimin, and Shiga toxin 2 proteins from Escherichia coli O157:H7 induces high levels of specific colostral antibodies that are transferred to newborn calves. J. Dairy Sci. 2012, 95, 3318-3326. [CrossRef]

42. Saeedi, P.; Yazdanparast, M.; Behzadi, E.; Salmanian, A.H.; Mousavi, S.L.; Nazarian, S.; Amani, J. A review on strategies for decreasing E. coli O157:H7 risk in animals. Microb. Pathog. 2017, 103, 186-195. [CrossRef] [PubMed]

43. Yao, S.; Ye, J.; Yang, Q.; Hu, Y.; Zhang, T.; Jiang, L.; Munezero, S.; Lin, K.; Cui, C. Occurrence and removal of antibiotics, antibiotic resistance genes, and bacterial communities in hospital wastewater. Environ. Sci. Pollut. Res. Int. 2021. online ahead of print. [CrossRef] [PubMed]

44. Martinez, J.L. General principles of antibiotic resistance in bacteria. Drug Discov. Today Technol. 2014, 11, 33-39. [CrossRef] [PubMed]

45. Baquero, F.; Martínez, J.-L.; Cantón, R. Antibiotics and antibiotic resistance in water environments. Curr. Opin. Biotechnol. 2008, 19, 260-265. [CrossRef] [PubMed]

46. Deshazo, J.P.; Hoffman, M.A. A comparison of a multistate inpatient EHR database to the HCUP Nationwide Inpatient Sample. BMC Health Serv. Res. 2015, 15, 384. [CrossRef] [PubMed]

47. Cooke, J.; Llor, C.; Hopstaken, R.; Dryden, M.; Butler, C. Respiratory tract infections (RTIs) in primary care: Narrative review of C reactive protein (CRP) point-of-care testing (POCT) and antibacterial use in patients who present with symptoms of RTI. BMJ Open Respir. Res. 2020, 7, e000624. [CrossRef] [PubMed] 
48. Paruk, F.; Richards, G.; Scribante, J.; Bhagwanjee, S.; Mer, M.; Perrie, H. Antibiotic prescription practices and their relationship to outcome in South Africa: Findings of the prevalence of infection in South African intensive care units (PISA) study. S. Afr. Med. J. 2012, 102, 613-616. [CrossRef] [PubMed]

49. Foster, C.B.; Martinez, K.A.; Sabella, C.; Weaver, G.P.; Rothberg, M.B. Patient satisfaction and antibiotic prescribing for respiratory infections by telemedicine. Pediatrics 2019, 144, e20190844. [CrossRef] [PubMed]

50. Vrijens, B.; Urquhart, J. Patient adherence to prescribed antimicrobial drug dosing regimens. J. Antimicrob. Chemother. 2005, 55, 616-627. [CrossRef] [PubMed]

51. Llor, C.; Hernández, S.; Bayona, C.; Moragas, A.; Sierra, N.; Hernández, M.; Miravitlles, M. A study of adherence to antibiotic treatment in ambulatory respiratory infections. Int. J. Infect. Dis. 2013, 17, e168-e172. [CrossRef]

52. O'Connell, K.M.G.; Hodgkinson, J.T.; Sore, H.F.; Welch, M.; Salmond, G.P.C.; Spring, D.R. Combating multidrug-resistant bacteria: Current strategies for the discovery of novel antibacterials. Angew. Chem. Int. Ed. 2013, 52, 10706-10733. [CrossRef]

53. Foudraine, D.E.; Strepis, N.; Stingl, C.; ten Kate, M.T.; Verbon, A.; Klaassen, C.H.W.; Goessens, W.H.F.; Luider, T.M.; Dekker, L.J.M. Exploring antimicrobial resistance to beta-lactams, aminoglycosides and fluoroquinolones in E. coli and K. pneumoniae using proteogenomics. Sci. Rep. 2021, 11, 12472. [CrossRef]

54. Cui, L.; Murakami, H.; Kuwahara-Arai, K.; Hanaki, H.; Hiramatsu, K. Contribution of a thickened cell wall and its glutamine nonamidated component to the vancomycin resistance expressed by Staphylococcus aureus Mu50. Antimicrob. Agents Chemother. 2000, 44, 2276-2285. [CrossRef] [PubMed]

55. Bokhary, H.; Pangesti, K.N.A.; Rashid, H.; Abd El Ghany, M.; Hill-Cawthorne, G.A. Travel-related antimicrobial resistance: A systematic review. Trop. Med. Infect. Dis. 2021, 6, 11. [CrossRef]

56. Pioletti, M.; Schlünzen, F.; Harms, J.; Zarivach, R.; Glühmann, M.; Avila, H.; Bashan, A.; Bartels, H.; Auerbach, T.; Jacobi, C.; et al. Crystal structures of complexes of the small ribosomal subunit with tetracycline, edeine and IF3. EMBO J. 2001, 20, 1829-1839. [CrossRef] [PubMed]

57. Brodersen, D.E.; Clemons, W.M.; Carter, A.P.; Morgan-Warren, R.J.; Wimberly, B.T.; Ramakrishnan, V. The structural basis for the action of the antibiotics tetracycline, pactamycin, and hygromycin B, on the 30S ribosomal subunit. Cell 2000, 103, 1143-1154. [CrossRef]

58. Lima, L.M.; da Silva, B.N.M.; Barbosa, G.; Barreiro, E.J. $\beta$-lactam antibiotics: An overview from a medicinal chemistry perspective. Eur. J. Med. Chem. 2020, 208, 112829. [CrossRef] [PubMed]

59. Hansen, J.L.; Ippolito, J.A.; Ban, N.; Nissen, P.; Moore, P.B.; Steitz, T.A. The structures of four macrolide antibiotics bound to the large ribosomal subunit. Mol. Cell 2002, 10, 117-128. [CrossRef]

60. Tu, D.; Blaha, G.; Moore, P.B.; Steitz, T.A. Structures of MLSBK antibiotics bound to mutated large ribosomal subunits provide a structural explanation for resistance. Cell 2005, 121, 257-270. [CrossRef] [PubMed]

61. Berisio, R.; Schluenzen, F.; Harms, J.; Bashan, A.; Auerbach, T.; Baram, D.; Yonath, A. Structural insight into the role of the ribosomal tunnel in cellular regulation. Nat. Struct. Biol. 2003, 10, 366-370. [CrossRef] [PubMed]

62. Bradford, P.A.; Urban, C.; Mariano, N.; Projan, S.J.; Rahal, J.J.; Bush, K. Imipenem resistance in Klebsiella pneumoniae is associated with the combination of ACT-1, a plasmid-mediated AmpC-lactamase, and the loss of an outer membrane protein. Antimicrob. Agents Chemother. 1997, 41, 563-569. [CrossRef]

63. Zgurskaya, H.; Blair, J.M.A.; Nikaido, H.; Nicolas-Chanoine, M.-H.; Guyot, K.; Mayer, N.; Dumont, E.; Pagès, J.-M. Interplay between membrane permeability and enzymatic barrier leads to antibiotic-dependent resistance in Klebsiella Pneumoniae. Front. Microbiol. 2018, 9, 1422.

64. Miyoshi-Akiyama, T.; Tada, T.; Ohmagari, N.; Hung, N.V.; Tharavichitkul, P.; Pokhrel, B.M.; Gniadkowski, M.; Shimojima, M.; Kirikae, T. Emergence and spread of epidemic multidrug-resistant Pseudomonas aeruginosa. Genome Biol. Evol. 2017, 9, 3238. [CrossRef]

65. Science, M.; Timberlake, K.; Morris, A.; Read, S.; Le Saux, N. Quality metrics for antimicrobial stewardship programs. Pediatrics 2019, 143, e20182372. [CrossRef]

66. Mendelson, M. Role of antibiotic stewardship in extending the age of modern medicine. S. Afr. Med. J. 2015, 105, 414-419. [CrossRef]

67. Chatterjee, M.; Pushkaran, A.C.; Vasudevan, A.K.; Menon, K.K.N.; Biswas, R.; Mohan, C.G. Understanding the adhesion mechanism of a mucin binding domain from Lactobacillus fermentum and its role in enteropathogen exclusion. Int. J. Biol. Macromol. 2018, 110, 598-607. [CrossRef] [PubMed]

68. Revitt-Mills, S.A.; Robinson, A. Antibiotic-induced mutagenesis: Under the microscope. Front. Microbiol. 2020, 11, 585175. [CrossRef]

69. Ruusala, T.; Andersson, D.; Ehrenberg, M.; Kurland, C.G. Hyper-accurate ribosomes inhibit growth. EMBO J. 1984, 3, $2575-2580$. [CrossRef]

70. Wolter, D.J.; Scott, A.; Armbruster, C.R.; Whittington, D.; Edgar, J.S.; Qin, X.; Buccat, A.M.; Mcnamara, S.; Blackledge, M.; Waalkes, A.; et al. Repeated isolation of an antibiotic-dependent and temperature-sensitive mutant of Pseudomonas aeruginosa from a cystic fibrosis patient. J. Antimicrob. Chemother. 2021, 76, 616-625. [CrossRef]

71. Suh, M.-J.; Keasey, S.L.; Brueggemann, E.E.; Ulrich, R.G. Antibiotic-dependent perturbations of extended spectrum beta-lactamase producing Klebsiella pneumoniae proteome. Proteomics 2017, 17, 1700003. [CrossRef] 
72. Shen, B.; Remzi, F.H.; Lopez, A.R.; Queener, E. Rifaximin for maintenance therapy in antibiotic-dependent pouchitis. BMC Gastroenterol. 2008, 8, 26. [CrossRef]

73. Soucy, S.M.; Huang, J.; Gogarten, J.P. Horizontal gene transfer: Building the web of life. Nat. Rev. Genet. 2015, 16, 472-482. [CrossRef] [PubMed]

74. Noble, W.C.; Virani, Z.; Cree, R.G. Co-transfer of vancomycin and other resistance genes from Enterococcus faecalis NCTC 12201 to Staphylococcus aureus. FEMS Microbiol. Lett. 1992, 72, 195-198. [CrossRef]

75. Zhang, P.Y.; Xu, P.P.; Xia, Z.J.; Wang, J.; Xiong, J.; Li, Y.Z. Combined treatment with the antibiotics kanamycin and streptomycin promotes the conjugation of Escherichia coli. FEMS Microbiol. Lett. 2013, 348, 149-156. [CrossRef]

76. Prudhomme, M.; Attaiech, L.; Sanchez, G.; Martin, B.; Claverys, J.-P. Antibiotic stress induces genetic transformability in the human pathogen Streptococcus pneumoniae. Science 2006, 313, 89-92. [CrossRef] [PubMed]

77. Charpentier, X.; Polard, P.; Claverys, J.P. Induction of competence for genetic transformation by antibiotics: Convergent evolution of stress responses in distant bacterial species lacking SOS? Curr. Opin. Microbiol. 2012, 15, 570-576. [CrossRef] [PubMed]

78. Mao, E.F.; Lane, L.; Lee, J.; Miller, J.H. Proliferation of mutators in a cell population. J. Bacteriol. 1997, 179, 417-422. [CrossRef]

79. Vallianou, N.; Dalamaga, M.; Stratigou, T.; Karampela, I.; Tsigalou, C. Do antibiotics cause obesity through long-term alterations in the gut microbiome? A review of current evidence. Curr. Obes. Rep. 2021, 10, 44-262. [CrossRef]

80. Di Caprio, J.M. Effects of Terramycin on the bacterial flora of the bowel in man. Arch. Intern. Med. 1950, 86, 649-657. [CrossRef] [PubMed]

81. Klevens, R.M.; Edwards, J.R.; Richards, C.L.; Horan, T.C.; Gaynes, R.P.; Pollock, D.A.; Cardo, D.M. Estimating health careassociated infections and deaths in U.S. hospitals, 2002. Public Health Rep. 2007, 122, 160-166. [CrossRef] [PubMed]

82. Rogawski, E.T.; Platts-Mills, J.A.; Seidman, J.C.; John, S.; Mahfuz, M.; Ulak, M.; Shrestha, S.K.; Soofi, S.B.; Yori, P.P.; Mduma, E.; et al. Use of antibiotics in children younger than two years in eight countries: A prospective cohort study. Bull. World Health Organ. 2017, 95, 49-61. [CrossRef] [PubMed]

83. Jin, S.; Zhao, D.; Cai, C.; Song, D.; Shen, J.; Xu, A.; Qiao, Y.; Ran, Z.; Zheng, Q. Low-dose penicillin exposure in early life decreases Th17 and the susceptibility to DSS colitis in mice through gut microbiota modification. Open Nat. Publ. Gr. 2017, 7, 43662. [CrossRef]

84. Lange, K.; Buerger, M.; Stallmach, A.; Bruns, T. Effects of antibiotics on gut microbiota. Dig. Dis. 2016, 34, 260-268. [CrossRef]

85. Hersh, A.L.; Shapiro, D.J.; Pavia, A.T.; Shah, S.S. Antibiotic prescribing in ambulatory pediatrics in the United States. Pediatrics 2011, 128, 1053-1061. [CrossRef]

86. Poole, N.M.; Shapiro, D.J.; Fleming-Dutra, K.E.; Hicks, L.A.; Hersh, A.L.; Kronman, M.P. Antibiotic prescribing for children in United States emergency departments: 2009-2014. Pediatrics 2019, 143, e20181056. [CrossRef]

87. El-Sayed, A.; Aleya, L.; Kamel, M. Microbiota's role in health and diseases. Environ. Sci. Pollut. Res. Int. 2021, 28, 36967-36983. [CrossRef] [PubMed]

88. Bohnhoff, B.Y.M.; Drake, B.L.; Miller, C.P. Effect of Streptomycin on susceptibility of intestinal tract to experimental Salmonella infection. Proc. Soc. Exp. Biol. Med. 1954, 86, 132-137. [CrossRef] [PubMed]

89. Dantas, S.T.A.; Rossi, B.F.; Bonsaglia, E.C.R.; Castilho, I.G.; Hernandes, R.T.; Fernandes, A.; Rall, V.L.M. Cross-contamination and biofilm formation by Salmonella enterica serovar Enteritidis on various cutting boards. Foodborne Pathog. Dis. 2018, 15, 81-85. [CrossRef] [PubMed]

90. McDonald, L.C. Effects of short- and long-course antibiotics on the lower intestinal microbiome as they relate to traveler's diarrhea. J. Travel Med. 2017, 24, S35-S38. [CrossRef]

91. Gradel, K.O.; Dethlefsen, C.; Ejlertsen, R.; Schønheyher, H.C.; Nielsen, H. Increased prescription rate of antibiotics prior to non-typhoid Salmonella infections: A one-year nested case-control study. Scand. J. Infect. Dis. 2008, 40, 635-641. [CrossRef]

92. Koningstein, M.; Simonsen, J.; Helms, M.; Hald, T.; Molbak, K. Antimicrobial use: A risk factor or a protective factor for acquiring campylobacteriosis? Clin. Infect. Dis. 2011, 53, 644-650. [CrossRef]

93. Baktash, A.; Terveer, E.M.; Zwittink, R.D.; Hornung, B.V.H.; Corver, J.; Kuijper, E.J.; Smits, W.K. Mechanistic insights in the success of fecal microbiota transplants for the treatment of Clostridium difficile infections. Front. Microbiol. 2018, 9, 1242. [CrossRef]

94. Allegretti, J.R.; Kearney, S.; Li, N.; Bogart, E.; Bullock, K.; Berber, G.K.; Bry, L.; Clish, C.B.; Alm, E.; Korzenik, J.R. Recurrent Clostridium difficile infection associates with distinct bile acid and microbiome profiles. Aliment. Pharmacol. Ther. 2016, 43, 1142-1153. [CrossRef]

95. Begley, M.; Gahan, C.G.M.; Hill, C. The interaction between bacteria and bile. FEMS Microbiol. Rev. 2005, 29, 625-651. [CrossRef]

96. Inagaki, T.; Moschetta, A.; Lee, Y.-K.; Peng, L.; Zhao, G.; Downes, M.; Yu, R.T.; Shelton, J.M.; Richardson, J.A.; Repa, J.J.; et al. Regulation of antibacterial defense in the small intestine by the nuclear bile acid receptor. Proc. Natl. Acad. Sci. USA 2006, 103, 3920-3925. [CrossRef]

97. Dudek-Wicher, R.K.; Junka, A.; Bartoszewicz, M. The influence of antibiotics and dietary components on gut microbiota. Gastroenterol. Rev. 2018, 13, 85-92. [CrossRef]

98. Osbelt, L.; Thiemann, S.; Smit, N.; Lesker, T.R.; Schröter, M.; Gálvez, E.J.C.; Schmidt-Hohagen, K.; Pils, M.C.; Mühlen, S.; Dersch, P.; et al. Variations in microbiota composition of laboratory mice influence Citrobacter rodentium infection via variable short-chain fatty acid production. PLoS Pathog. 2020, 16, e1008448. [CrossRef]

99. Venegas, D.P.; De La Fuente, M.K.; Landskron, G.; González, M.J.; Quera, R.; Dijkstra, G.; Harmsen, H.J.M.; Faber, K.N.; Hermoso, M.A. Short chain fatty acids (SCFAs)-mediated gut epithelial and immune regulation and its relevance for inflammatory bowel diseases. Front. Immunol. 2019, 10, 277. [CrossRef] 
100. Sorbara, M.T.; Dubin, K.; Littmann, E.R.; Moody, T.U.; Fontana, E.; Seok, R.; Leiner, I.M.; Taur, Y.; Peled, J.U.; van den Brink, M.R.M.; et al. Inhibiting antibiotic-resistant Enterobacteriaceae by microbiota-mediated intracellular acidification. J. Exp. Med. 2019, 216, 84-98. [CrossRef] [PubMed]

101. Tedesco, F.J.; Barton, R.W.; Alpers, D.H. Clindamycin-associated colitis. A prospective study. Ann. Intern. Med. 1974, 81, 429-433. [CrossRef]

102. Centers for Disease Control and Prevention. 2017 National and State Healthcare-Associated Infections Progress Report. 2019. Available online: https:/ / www.cdc.gov/hai/data/portal/progress-report.html (accessed on 8 August 2021).

103. Kampouri, E.; Croxatto, A.; Prod'hom, G.; Guery, B. Clostridioides difficile infection, still a long way to go. J. Clin. Med. 2021, 10, 389. [CrossRef] [PubMed]

104. Rupnik, M.; Wilcox, M.H.; Gerding, D.N. Clostridium difficile infection: New developments in epidemiology and pathogenesis. Nat. Rev. Microbiol. 2009, 7, 526-536. [CrossRef] [PubMed]

105. Fekety, R.; McFarland, L.V.; Surawicz, C.M.; Greenberg, R.N.; Elmer, G.W.; Mulligan, M.E. Recurrent Clostridium difficile diarrhea: Characteristics of and risk factors for patients enrolled in a prospective, randomized, double-blinded trial. Clin. Infect. Dis. 1997, 24, 324-333. [CrossRef] [PubMed]

106. McFarland, L.V.; Surawicz, C.M.; Rubin, M.; Fekety, R.; Elmer, G.W.; Greenberg, R.N. Recurrent Clostridium difficile disease: Epidemiology and clinical characteristics. Infect. Control Hosp. Epidemiol. 1999, 20, 43-50. [CrossRef]

107. Davies, K.A.; Longshaw, C.M.; Davis, G.L.; Bouza, E.; Barbut, F.; Barna, Z.; Delemée, M.; Fitzpatrick, F.; Ivanova, K.; Kuijper, E.; et al. Underdiagnosis of Clostridium difficile across Europe: The European, multicentre, prospective, biannual, pointprevalence study of Clostridium difficile infection in hospitalized patients with diarrhoea (EUCLID). Lancet. Infect. Dis. 2014, 14, 1208-1219. [CrossRef]

108. Leffler, D.A.; Lamont, J.T. Clostridium difficile infection. N. Engl. J. Med. 2015, 372, 1539-1548. [CrossRef] [PubMed]

109. Hensgens, M.P.M.; Goorhuis, A.; Dekkers, O.M.; Kuijper, E.J. Time interval of increased risk for Clostridium difficile infection after exposure to antibiotics. J. Antimicrob. Chemother. 2012, 67, 742-748. [CrossRef]

110. Loo, V.G.; Bourgault, A.-M.; Poirier, L.; Lamothe, F.; Michaud, S.; Turgeon, N.; Toye, B.; Beaudoin, A.; Frost, E.H.; Gilca, R.; et al. Host and pathogen factors for Clostridium difficile infection and colonization. N. Engl. J. Med. 2011, 365, 1693-1703. [CrossRef]

111. Eyre, D.W.; Griffiths, D.; Vaughan, A.; Golubchik, T.; Acharya, M.; O'Connor, L.; Crook, D.W.; Walker, A.S.; Peto, T.E.A. Asymptomatic Clostridium difficile colonization and onward transmission. PLoS ONE 2013, 8, e78445. [CrossRef] [PubMed]

112. Hung, Y.-P.; Lin, H.-J.; Wu, T.-C.; Liu, H.-C.; Lee, J.-C.; Lee, C.-I.; Wu, Y.-H.; Wan, L.; Tsai, P.-J.; Ko, W.-C. Risk factors of fecal toxigenic or non-toxigenic Clostridium difficile colonization: Impact of Toll-like receptor polymorphisms and prior antibiotic exposure. PLoS ONE 2013, 8, e69577. [CrossRef] [PubMed]

113. Czepiel, J.; Kędzierska, J.; Biesiada, G.; Birczyńska, M.; Perucki, W.; Nowak, P.; Garlicki, A. Epidemiology of Clostridium difficile infection: Results of a hospital-based study in Krakow, Poland. Epidemiol. Infect. 2015, 143, 3235-3243. [CrossRef]

114. Zacharioudakis, I.M.; Zervou, F.N.; Pliakos, E.E.; Ziakas, P.D.; Mylonakis, E. Colonization with toxinogenic C. difficile upon hospital admission, and risk of infection: A systematic review and meta-analysis. Am. J. Gastroenterol. 2015, 110, 381-390. [CrossRef] [PubMed]

115. Curry, S.R.; Muto, C.A.; Schlackman, J.L.; Pasculle, A.W.; Shutt, K.A.; Marsh, J.W.; Harrison, L.H. Use of multilocus variable number of tandem repeats analysis genotyping to determine the role of asymptomatic carriers in Clostridium difficile transmission. Clin. Infect. Dis. 2013, 57, 1094-1102. [CrossRef] [PubMed]

116. Longtin, Y.; Paquet-Bolduc, B.; Gilca, R.; Garenc, C.; Fortin, E.; Longtin, J.; Trottier, S.; Gervais, P.; Roussy, J.-F.; Lévesque, S.; et al. Effect of detecting and isolating Clostridium difficile carriers at hospital admission on the incidence of $C$. difficile infections: A quasi-experimental controlled study. JAMA Intern. Med. 2016, 176, 796-804. [CrossRef]

117. Johnson, S.; Louie, T.J.; Gerding, D.N.; Cornely, O.A.; Chasan-Taber, S.; Fitts, D.; Gelone, S.P.; Broom, C.; Davidson, D.M. Vancomycin, metronidazole, or tolevamer for Clostridium difficile infection: Results from two multinational, randomized, controlled trials. Clin. Infect. Dis. 2014, 59, 345-354. [CrossRef]

118. Mullish, B.H.; Williams, H.R.T. Clostridium difficile infection and antibiotic-associated diarrhoea. Clin. Med. J. 2018, 18, 237-241. [CrossRef]

119. Kelly, C.P.; LaMont, J.T. Clostridium difficile-more difficult than ever. N. Engl. J. Med. 2008, 359, 1932-1940. [CrossRef] [PubMed]

120. Martin, J.S.H.; Monaghan, T.M.; Wilcox, M.H. Clostridium difficile infection: Epidemiology, diagnosis and understanding transmission. Nat. Rev. Gastroenterol. Hepatol. 2016, 13, 206-216. [CrossRef] [PubMed]

121. Loo, V.G.; Poirier, L.; Miller, M.A.; Oughtin, M.; Libman, M.D.; Michaud, S.; Bourgault, A.-M.; Nguyen, T.; Frenette, C.; Kelly, M.; et al. A predominantly clonal multi-institutional outbreak of Clostridium difficile-associated diarrhea with high morbidity and mortality. N. Engl. J. Med. 2005, 353, 2442-2449. [CrossRef] [PubMed]

122. McDonald, L.C.; Killgore, G.E.; Thompson, A.; Owens, R.C.; Kazakova, S.V.; Sambol, S.P.; Johnson, S.; Gerding, D.N. An epidemic, toxin gene-variant strain of Clostridium difficile. N. Engl. J. Med. 2005, 353, 2433-2441. [CrossRef] [PubMed]

123. Van Nood, E.; Vrieze, A.; Nieuwdorp, M.; Fuentes, S.; Zoetendal, E.G.; de Vos, W.M.; Visser, C.E.; Kuijper, E.J.; Bartelsman, J.F.W.M.; Tijssen, J.G.P.; et al. Duodenal infusion of donor feces for recurrent Clostridium difficile. N. Engl. J. Med. 2013, 368, 407-415. [CrossRef] [PubMed] 
124. Cammarota, G.; Masucci, L.; Ianiro, G.; Bibbò, S.; Dinoi, G.; Costamagna, G.; Sanguinetti, M.; Gasbarrini, A. Randomized clinical trial: Faecal microbiota transplantation by colonoscopy vs. vancomycin for the treatment of recurrent Clostridium difficile infection. Aliment. Pharmacol. Ther. 2015, 41, 835-843. [CrossRef]

125. Alonso, C.D.; Mahoney, M.V. Bezlotoxumab for the prevention of Clostridium difficile infection: A review of current evidence and safety profile. Infect. Drug Resist. 2019, 12, 1-9. [CrossRef]

126. Louie, T.J.; Miller, M.A.; Mullane, K.M.; Weiss, K.; Lentnek, A.; Golan, Y.; Gorbach, S.; Sears, P.; Shue, Y.-K. Fidaxomicin versus vancomycin for Clostridium difficile infection. N. Engl. J. Med. 2011, 364, 422-431. [CrossRef]

127. Cornely, O.A.; Miller, M.A.; Louie, T.J.; Crook, D.W.; Gorbach, S.L. Treatment of first recurrence of Clostridium difficile infection: Fidaxomicin versus vancomycin. Clin. Infect. Dis. 2012, 55 (Suppl. S2), S154-S161. [CrossRef]

128. Fleming-Dutra, K.E.; Hersh, A.L.; Shapiro, D.J.; Bartoces, M.; Enns, E.A.; File, T.M.; Finkelstein, J.A.; Gerber, J.S.; Hyun, D.Y.; Linder, J.A.; et al. Prevalence of inappropriate antibiotic prescriptions among U.S. ambulatory care visits, 2010-2011. JAMA 2016, 315, 1864-1873. [CrossRef] [PubMed]

129. Hagiya, H.; Kokado, R.; Ueda, A.; Okuno, H.; Morii, D.; Hamaguchi, S.; Yamamoto, N.; Yoshida, H.; Tomono, K. Association of adverse drug events with broad-spectrum antibiotic use in hospitalized patients: A single-center study. Intern. Med. 2019, 58, $2621-2625$. [CrossRef] [PubMed]

130. Melton-Celsa, A.; Mohawk, K.; Teel, L.; O’Brien, A. Pathogenesis of Shiga-toxin producing Escherichia coli. Curr. Top. Microbiol. Immunol. 2012, 357, 67-103. [PubMed]

131. Tam, P.J.; Lingwood, C.A. Membrane cytosolic translocation of verotoxin A1 subunit in target cells. Microbiology 2007, 153, 2700-2710. [CrossRef] [PubMed]

132. Petruzziello-Pellegrini, T.N.; Moslemi-Naeini, M.; Marsden, P.A. New insights into Shiga toxin-mediated endothelial dysfunction in hemolytic uremic syndrome. Virulence 2013, 4, 556-563. [CrossRef]

133. Andreoli, S.P.; Trachtman, H.; Acheson, D.W.K.; Siegler, R.L.; Obrig, T.G. Hemolytic uremic syndrome: Epidemiology, pathophysiology, and therapy. Pediatr. Nephrol. 2002, 17, 293-298. [CrossRef]

134. Mayer, C.L.; Leibowitz, C.S.; Kurosawa, S.; Stearns-Kurosawa, D.J. Shiga toxins and the pathophysiology of hemolytic uremic syndrome in humans and animals. Toxins 2012, 4, 1261-1287. [CrossRef]

135. Zhang, X.; McDaniel, A.D.; Wolf, L.E.; Keusch, G.T.; Waldor, M.K.; Acheson, D.W. Quinolone antibiotics induce Shiga toxinencoding bacteriophages, toxin production, and death in mice. J. Infect. Dis. 2000, 181, 664-670. [CrossRef] [PubMed]

136. Todar, K. (Ed.) Todar's Online Textbook of Bacteriology; Kennish Todar: Madison, WI, USA, 2020. Available online: http:// textbookofbacteriology.net/ (accessed on 8 August 2021).

137. Department of Health, Education, and Welfare, Public Health Service, Food and Drug Administration. Bacterial Endotoxins/Pyrogens: In Inspection Technical Guide. 2014. Available online: https:/ / www.fda.gov/inspections-compliance-enforcement-and-criminalinvestigations/inspection-technical-guides/bacterial-endotoxinspyrogens (accessed on 18 August 2021).

138. Gorbet, M.B.; Sefton, M.V. Review: Biomaterial-associated thrombosis: Roles of coagulation factors, complement, platelets and leukocytes. Biomaterials 2004, 25, 219-241. [CrossRef]

139. Dhakal, A.; Sbar, E. Jarisch Herxheimer Reaction; StatPearls Publishing: Treasurer Island, FL, USA, 2021. Available online: https:/ / www.ncbi.nlm.nih.gov/books/NBK557820/ (accessed on 18 August 2021).

140. Shepard, C.C.; Levy, L.; Fasal, P. Further experience with the rapid bactericidal effect of rifampin on Mycobacterium leprae. Am. J. Trop. Med. Hyg. 1974, 23, 1120-1124. [CrossRef] [PubMed]

141. Minasyan, H. Sepsis: Mechanisms of bacterial injury to the patient. Scand. J. Trauma Resusc. Emerg. Med. 2019, 27, 19. [CrossRef] [PubMed]

142. Bone, R.C. Gram-negative sepsis: A dilemma of modern medicine. Clin. Microbiol. Rev. 1993, 6, 57-68. [CrossRef]

143. Gerber, J.S.; Ross, R.K.; Bryan, M.; Localio, A.R.; Szymczak, J.E.; Wasserman, R.; Barkman, D.; Odeniyi, F.; Conaboy, K.; Bell, L.; et al. Association of broad- vs. narrow-spectrum antibiotics with treatment failure, adverse events, and quality of life in children with acute respiratory tract infections. J. Am. Med. Assoc. 2017, 318, 2325-2336. [CrossRef] [PubMed]

144. Melander, R.J.; Zurawski, D.V.; Melander, C. Narrow-spectrum antibacterial agents. Med. Chem. Comm. 2018, 9, 12-21. [CrossRef] [PubMed]

145. Kolár, M.; Urbánek, K.; Látal, T. Antibiotic selective pressure and development of bacterial resistance. Int. J. Antimicrob. Agents 2001, 17, 357-363. [CrossRef]

146. Abt, M.C.; Pamer, E.G. Commensal bacteria mediated defenses against pathogens. Curr. Opin. Immunol. 2014, 29 , 16-22. [CrossRef]

147. Prescott, J.F. The resistance tsunami, antimicrobial stewardship, and the golden age of microbiology. Vet. Microbiol. 2014, 171, 273-278. [CrossRef] [PubMed]

148. Wang, C.H.; Hsieh, Y.H.; Powers, Z.M.; Kao, C.Y. Defeating antibiotic-resistant bacteria: Exploring alternative therapies for a post-antibiotic era. Int. J. Mol. Sci. 2020, 21, 1061. [CrossRef] [PubMed]

149. Miller, W.R.; Murray, B.E.; Rice, L.B.; Arias, C.A. Resistance in vancomycin-resistant Enterococci. Infect. Dis. Clin. N. Am. 2020, 34, 751-771. [CrossRef]

150. Savoldi, A.; Carrara, E.; Piddock, L.J.V.; Franceschi, F.; Ellis, S.; Chiamenti, M.; Bragantini, D.; Righi, E.; Tacconelli, E. The role of combination therapy in the treatment of severe infections caused by carbapenem resistant Gram-negatives: A systematic review of clinical studies. BMC Infect. Dis. 2021, 21, 545. [CrossRef] 
151. Hall, J.D.; Duncan-Gould, N.W.; Siddiqi, N.A.; Kelly, J.N.; Hoeferlin, L.A.; Morrison, S.J.; Wyatt, J.K. Cytosporone E: Racemic synthesis and preliminary antibacterial testing. Bioorganic. Med. Chem. 2005, 13, 1409-1413. [CrossRef]

152. Tyers, M.; Wright, G.D. Drug combinations: A strategy to extend the life of antibiotics in the 21st century. Nat. Rev. Microbiol. 2019, 17, 141-155. [CrossRef]

153. Allison, M.G.; Heil, E.L.; Hayes, B.D. Appropriate Antibiotic Therapy. Emerg. Med. Clin. N. Am. 2017, 35, 25-42. [CrossRef] [PubMed]

154. Annunziato, G. Strategies to overcome antimicrobial resistance (AMR) making use of non-essential target inhibitors: A review. Int. J. Mol. Sci. 2019, 20, 5844. [CrossRef] [PubMed]

155. Papp-Wallace, K.M.; Mack, A.R.; Taracila, M.A.; Bonomo, R.A. Resistance to novel $\beta$-lactam- $\beta$-lactamase inhibitor combinations: The "Price of Progress". Infect. Dis. Clin. N. Am. 2020, 34, 773-819. [CrossRef] [PubMed]

156. De la Torre, B.G.; Albericio, F. The pharmaceutical industry in 2019. An analysis of FDA drug approvals from the perspective of molecules. Molecules 2020, 25, 745. [CrossRef]

157. Kim, S.A.; Jang, M.J.; Kim, S.Y.; Yang, Y.; Pavlidis, H.O.; Ricke, S.C. Potential for prebiotics as feed additives to limit foodborne Campylobacter establishment in the poultry gastrointestinal tract. Front. Microbiol. 2019, 10, 91. [CrossRef]

158. Elison, E.; Vigsnaes, L.K.; Rindom Krogsgaard, L.; Rasmussen, J.; Sørensen, N.; Mcconnell, B.; Hennet, T.; Sommer, M.O.A.; Bytzer, P. Oral supplementation of healthy adults with 2'-O-fucosyllactose and lacto-N-neotetraose is well tolerated and shifts the intestinal microbiota. Br. J. Nutr. 2016, 116, 1356-1368. [CrossRef]

159. Gareau, G.; Wine, E.; Reardon, C.; Sherman, P.M. Probiotics prevent death caused by Citrobacter rodentium infection in neonatal mice. J. Infect. Dis. 2009, 201, 81-91. [CrossRef]

160. Fonseca, H.C.; de Sousa Melo, D.; Ramos, C.L.; Dias, D.R.; Schwan, R.F. Probiotic properties of Lactobacilli and their ability to inhibit the adhesion of enteropathogenic bacteria to caco-2 and HT-29 cells. Probiotics Antimicrob. Proteins 2020, 13, 102-112. [CrossRef]

161. Yang, B.; Lu, P.; Li, M.-X.; Cai, X.-L.; Xiong, W.-Y.; Hou, H.-J.; Ha, X.-Q. A meta-analysis of the effects of probiotics and synbiotics in children with acute diarrhea. Medicine 2019, 98, e16618. [CrossRef]

162. Manley, K.J.; Fraenkel, M.B.; Mayall, B.C.; Power, D.A. Probiotic treatment of vancomycin-resistant enterococci: A randomised controlled trial. Med. J. Aust. 2007, 186, 454-457. [CrossRef] [PubMed]

163. Kim, A.S. Using the good to beat out the bad: Probiotics for eliminating vancomycin-resistant enterococci colonization. J. Clin. Gastroenterol. 2011, 45, 844-845. [CrossRef]

164. Panigrahi, P.; Parida, S.; Nanda, N.C.; Satpathy, R.; Pradhan, L.; Chandel, D.S.; Baccaglini, L.; Mohapatra, A.; Mohapatra, S.S.; Misra, P.R.; et al. A randomized synbiotic trial to prevent sepsis among infants in rural India. Nature 2017, 548, 407-412. [CrossRef] [PubMed]

165. Wiencek, J.; Nichols, J. Issues in the practical implementation of POCT: Overcoming challenges. Expert Rev. Mol. Diagn. 2016, 16, 415-422. [CrossRef] [PubMed]

166. Ferreira, C.E.S.; Guerra, J.C.C.; Slhessarenko, N.; Scartezini, M.; Franco, C.N.; Colombini, M.P.; Berlitz, F.; Machado, A.M.O.; Campana, G.A.; Faulhaber, A.C.L.; et al. Point-of-care testing: General aspects. Clin. Lab. 2018, 64, 1-9. [CrossRef]

167. Haldrup, S.; Thomsen, R.W.; Bro, F.; Skov, R.; Bjerrum, L.; Søgaard, M. Microbiological point of care testing before antibiotic prescribing in primary care: Considerable variations between practices. BMC Fam. Pract. 2017, 18, 9. [CrossRef]

168. Price, C.P.; Smith, S.; den Brual, A.V. Improving the quality of point-of-care testing. Fam. Pract. 2018, 35, 358-364. [CrossRef]

169. Mysaadm, S.M.A. Point-of-care testing and equity. Arch. Pathol. Lab. Med. 2020, 144, 1191-1192.

170. Weihser, P.; Giles, D. Establishing an ambulatory care service using point-of-care testing diagnostics. Br. J. Hosp. Med. 2018, 79, 520-523. [CrossRef]

171. Poole, S.; Townsend, J.; Wertheim, H.; Kidd, S.P.; Welte, T.; Schuetz, P.; Luyt, C.-E.; Beishuizen, A.; Jensen, J.-U.S.; Del Castillo, J.G.; et al. How are rapid diagnostic tests for infectious diseases used in clinical practice: A global survey by the International Society of Antimicrobial Chemotherapy (ISAC). Eur. J. Clin. Microbiol. Infect. Dis. 2021, 40, 429-434. [CrossRef] [PubMed]

172. Saraswati, K.; Day, N.P.J.; Mukaka, M.; Blacksell, S.D. Scrub typhus point-of-care testing: A systematic review and meta-analysis. PLoS Negl. Trop. Dis. 2018, 12, e0006330. [CrossRef] [PubMed]

173. Mak, G.C.; Cheng, P.K.; Lau, S.S.; Wong, K.K.; Lau, C.; Lam, E.T.; Chan, R.C.; Tsang, D.N. Evaluation of rapid antigen test for detection of SARS-CoV-2 virus. J. Clin. Virol. 2020, 129, 104500. [CrossRef]

174. Hermoso, J.A.; García, J.L.; García, P. Taking aim on bacterial pathogens: From phage therapy to enzybiotics. Curr. Opin. Microbiol. 2007, 10, 461-472. [CrossRef] [PubMed]

175. Kawacka, I.; Olejnik-Schmidt, A.; Schmidt, M.; Sip, A. Effectiveness of phage-based inhibition of Listeria monocytogenes in food products and food processing environments. Microorganisms 2020, 8, 1764. [CrossRef]

176. Zeng, Y.; Wang, Z.; Zou, T.; Chen, J.; Li, G.; Zheng, L.; Li, S.; You, J. Bacteriophage as an alternative to antibiotics promotes growth performance by regulating intestinal inflammation, intestinal barrier function and gut microbiota in weaned piglets. Front. Vet. Sci. 2021, 8, 623899. [CrossRef]

177. Jin, L.; Engelhart, A.E.; Adamala, K.P.; Szostak, J.W. Preparation, purification, and use of fatty acid-containing liposomes. J. Vis. Exp. 2018, 132, 57324. [CrossRef] 
178. Fortuna, W.; Międzybrodzki, R.; Weber-Dąbrowska, B.; Górski, A. Bacteriophage therapy in children: Facts and prospects. Med. Sci. Monit. 2008, 14, 126-132.

179. Abedon, S.T.; LeJeune, J.T. Why Bacteriophage encode exotoxins and other virulence factors. Evol. Bioinform. Online 2005, 1, 97-110. [CrossRef]

180. Moludi, J.; Maleki, V.; Jafari-Vayghyan, H.; Vaghef-Mehrabany, E.; Alizadeh, M. Metabolic endotoxemia and cardiovascular disease: A systematic review about potential roles of prebiotics and probiotics. Clin. Exp. Pharmacol. Physiol. 2020, 47, 927-939. [CrossRef]

181. American Board of Internal Medicine. Choosing Wisely (R). Available online: https://www.choosingwisely.org/ (accessed on 17 September 2021).

182. Public Health England. Antimicrobial Stewardship: Start Smart-Then Focus. Available online: https://www.gov.uk/ government/publications/antimicrobial-stewardship-start-smart-then-focus (accessed on 17 September 2021).

183. Australian Commission on Safety and Quality in Health Care. Action 3.15. Available online: https://www.safetyandquality. gov.au/standards/nsqhs-standards/preventing-and-controlling-healthcare-associated-infection-standard/antimicrobialstewardship/action-315 (accessed on 17 September 2021).

184. AUPA-Russia. Russia-Alliance for the Prudent Use of Antibiotics. Available online: https://apua.org/russia (accessed on 17 September 2021).

185. ReAct. Antimicrobial Stewardship in South Africa. Available online: https://www.reactgroup.org/toolbox/rational-use/ examples-from-the-field/antimicrobial-stewardship-in-south-africa/ (accessed on 17 September 2021).

186. APUA-Brazil. Brazil-Alliance for the Prudent Use of Antibiotics. Available online: https://apua.org/brazil-1 (accessed on 17 September 2021).

187. Australian Commission on Safety and Quality in Health Care. Antimicrobial Stewardship Clinical Care Standard. Available online: https: / / www.safetyandquality.gov.au/our-work/clinical-care-standards/antimicrobial-stewardship-clinical-care-standard (accessed on 24 September 2021).

188. Xiao, Y. Antimicrobial stewardship in China: Systems, actions and future strategies. Clin. Infect. Dis. 2018, 67, S135-S141. [CrossRef]

189. Cheng, A.H.Y.; Campbell, S.; Chartier, L.B.; Goddard, T.; Magee, K.; Mcewen, J.; Kapur, A.K.; Holroyd, B.R.; Upadhye, S.; Couperthwaite, S.; et al. Choosing Wisely Canada ${ }^{\circledR}$ : Five tests, procedures and treatments to question in emergency medicine. CJEM 2017, 19, S9-S17. [CrossRef]

190. Using Antibiotics Wisely_Choosing Wisely Canada. Available online: https://choosingwiselycanada.org/campaign/antibiotics/ (accessed on 17 September 2021).

191. Boscia, J.A.; Kobasa, W.D.; Abrutyn, E.; Levison, M.E.; Kaplan, A.M.; Kaye, D. A lack of association between bacteriuria and symptoms in the elderly. Am. J. Med. 1986, 81, 979-982. [CrossRef]

192. Nicolle, L.E.; Mayhew, W.J.; Bryan, L. Prospective randomized comparison of therapy and no therapy for asymptomatic bacteriuria in institutionalized elderly women. Am. J. Med. 1987, 83, 27-33. [CrossRef]

193. Nicolle, L.E.; SHEA Long-Term-Care-Committee. Urinary tract infections in long-term-care facilities. Infect. Control Hosp. Epidemiol. 2001, 22, 167-175. [CrossRef]

194. Juthani-Mehta, M.; Tinetti, M.; Perrelli, E.; Towle, V.; Quagliarello, V. Role of dipstick testing in the evaluation of urinary tract infection in nursing home residents. Infect. Control Hosp. Epidemiol. 2007, 28, 889-891. [CrossRef] [PubMed]

195. Volpp, K.G.; Loewenstein, G.; Asch, D.A. Choosing Wisely: Low-value services, utilization, and patient cost sharing. JAMA 2012, 308, 1635-1636. [CrossRef] [PubMed]

196. Sullivan, W. Why "Choosing Wisely" Won't Protect You in a Lawsuit. Medscape Business of Medicine. Available online: https: //www.medscape.com/viewarticle/837399 (accessed on 11 August 2021).

197. Arroll, B.; Kenealy, T.; Kerse, N. Do delayed prescriptions reduce antibiotic use in respiratory tract infections? A systematic review. Br. J. Gen. Pract. 2003, 53, 871-877. [PubMed]

198. Spurling, G.K.; Del Mar, C.B.; Dooley, L.; Foxlee, R.; Farley, R. Delayed antibiotics for respiratory infections. Cochrane Database Syst. Rev. 2013, 4, CD004417.

199. Little, P.; Moore, M.; Kelly, J.; Williamson, I.; Leydon, G.; Mcdermott, L.; Mullee, M.; Stuart, B. Delayed antibiotic prescribing strategies for respiratory tract infections in primary care: Pragmatic, factorial, randomized controlled trial. BMJ 2014, 348 , g1606. [CrossRef] [PubMed]

200. Cahir, C.; Fahey, T.; Tilson, L.; Teljeur, C.; Bennett, K. Proton pump inhibitors: Potential cost reductions by applying prescribing guidelines. BMC Health Serv. Res. 2012, 12, 408. [CrossRef]

201. Tannenbaum, C.; Martin, P.; Tamblyn, R.; Benedetti, A.; Ahmed, S. Reduction of inappropriate benzodiazepine prescriptions among older adults through direct patient education. JAMA Intern. Med. 2014, 174, 890-898. [CrossRef] [PubMed]

202. Kastner, M.; Makarski, J.; Mossman, K.; Harris, K.; Hayden, L.; Giraldo, M.; Sharma, D.; Asalya, M.; Jussaume, L.; Eisen, D.; et al An idea worth sustaining: Evaluation of the sustainability potential of Choosing Wisely across Ontario community hospitals and family health teams. Res. Sq. 2020. [CrossRef]

203. Levinson, W.; Kallewaard, M.; Bhatia, R.S.; Wolfson, D.; Shortt, S.; Kerr, E.A. 'Choosing Wisely': A growing international campaign. BMJ Qual. Saf. 2015, 24, 167-174. [CrossRef]

204. Siemens, D.R.; Finelli, A. Choosing Wisely Canada: It's our turn. Can. Urol. Assoc. J. 2014, 8, 223-224. [CrossRef] 
205. Clement, F.; Charlton, B. Challenges in Choosing Wisely's international future: Support, evidence, and burnout. JAMA Intern. Med. 2015, 175, 644-645. [CrossRef]

206. Bowdle, A.; Munoz-Price, L.S. Preventing infection of patients and healthcare workers should be the new normal in the era of novel coronavirus epidemics. Anesthesiology 2020, 132, 1292-1295. [CrossRef] [PubMed]

207. Chiu, N.C.; Chi, H.; Tai, Y.L.; Peng, C.C.; Tseng, C.Y.; Chen, C.C.; Tan, B.F.; Lin, C.Y. Impact of wearing masks, hand hygiene, and social distancing on influenza, enterovirus, and all-cause pneumonia during the coronavirus pandemic: Retrospective national epidemiological surveillance study. J. Med. Internet Res. 2020, 22, e21257. [CrossRef] [PubMed]

208. Tiri, B.; Sensi, E.; Marsiliani, V.; Cantarini, M.; Priante, G.; Vernelli, C.; Martella, L.A.; Costantini, M.; Mariottini, A.; Andreani, P.; et al. Antimicrobial stewardship program, COVID-19, and infection control: Spread of carbapenem-resistant Klebsiella Pneumoniae colonization in ICU COVID-19 patients. What did not work? J. Clin. Med. 2020, 9, 2744. [CrossRef]

209. Scopetti, M.; Santurro, A.; Tartaglia, R.; Frati, P.; Fineschi, V.; Sciences, O. Neglected tropical diseases in non-endemic countries in the era of COVID-19 pandemic: The great forgotten. J. Travel Med. 2020, 28, taaa179.

210. Hollingsworth, T.D.; Mwinzi, P.; Vasconcelos, A.; de Vlas, S.J. Evaluating the potential impact of interruptions to neglected tropical disease programmes due to COVID-19. Trans. R. Soc. Trop. Med. Hyg. 2021, 115, 201-204. [CrossRef] [PubMed]

211. Molyneux, D.; Bush, S.; Bannerman, R.; Downs, P.; Shu'aibu, J.; Boko-Collins, P.; Radvan, I.; Wohlgemuth, L.; Boyton, C. Neglected tropical diseases activities in Africa in the COVID-19 era: The need for a "hybrid" approach in COVID-endemic times. Infect. Dis. Poverty 2021, 10, 1. [CrossRef] [PubMed]

212. Brooker, S.J.; Ziumbe, K.; Negussu, N.; Crowley, S.; Hammami, M. Neglected tropical disease control in a world with COVID-19: An opportunity and a necessity for innovation. Trans. R. Soc. Trop. Med. Hyg. 2021, 115, 205-207. [CrossRef]

213. Allen, R.C.; Popat, R.; Diggle, S.P.; Brown, S.P. Targeting virulence: Can we make evolution-proof drugs? Nat. Rev. Microbiol. 2014, 12, 300-308. [CrossRef]

214. Low, C.X.; Tan, L.T.-H.; Ab Mutalib, N.-S.; Pusparajah, P.; Goh, B.-H.; Chan, K.-G.; Letchumanan, V.; Lee, L.-H. Unveiling the impact of antibiotics and alternative methods for animal husbandry: A review. Antibiotics 2021, 10, 578. [CrossRef]

215. Martínez, J.L. The antibiotic resistome: Challenge and opportunity for therapeutic intervention. Future Med. Chem. 2012, 4, 347-359. [CrossRef]

216. Cheng, G.; Hao, H.; Xie, S.; Wang, X.; Dai, M.; Huang, L.; Yuan, Z. Antibiotic alternatives: The substitution of antibiotics in animal husbandry? Front. Microbiol. 2014, 5, 217. [CrossRef]

217. Rello, J.; Bunsow, E.; Perez, A. What if there were no new antibiotics? A look at alternatives. Expert Rev. Clin. Pharmacol. 2016, 9 , 1547-1555. [CrossRef]

218. Fernandez-Brando, R.J.; Yamaguchi, N.; Tahoun, A.; McAteer, S.P.; Gillespie, T.; Wang, D.; Argyle, S.A.; Palermo, M.S.; Gally, D.L. Type III secretion-dependent sensitivity of Escherichia coli O157 to specific ketolides. Antimicrob. Agents Chemother. 2016, 60, 459-470. [CrossRef] [PubMed]

219. Rasmussen, T.B.; Bjarnsholt, T.; Skindersoe, M.E.; Hentzer, M.; Kristoffersen, P.; Köte, M.; Nielsen, J.; Eberl, L.; Givskov, M. Screening for quorum-sensing inhibitors (QSI) by use of a novel genetic system, the QSI selector. J. Bacteriol. 2005, 187, 1799-1814. [CrossRef] [PubMed]

220. Hentzer, M.; Wu, H.; Andersen, J.B.; Riedel, K.; Rasmussen, T.B.; Bagge, N.; Kumar, N.; Schembri, M.A.; Song, Z.; Kristoffersen, P.; et al. Attenuation of Pseudomonas aeruginosa virulence by quorum sensing inhibitors. EMBO J. 2003, 22, 3803-3815. [CrossRef]

221. Hu, Y.; Huang, H.; Cheng, X.; Shu, X.; White, A.P.; Stavrinides, J.; Köster, W.; Zhu, G.; Zhao, Z.; Wang, Y. A global survey of bacterial type III secretion systems and their effectors. Environ. Microbiol. 2017, 19, 3879-3895. [CrossRef]

222. Smith, K.M.; Bu, Y.; Suga, H. Induction and inhibition of Pseudomonas aeruginosa quorum sensing by synthetic autoinducer analogs. Chem. Biol. 2003, 10, 81-89. [CrossRef]

223. Alfano, J.R.; Collmer, A. Type III secretion system effector proteins: Double agents in bacterial disease and plant defense. Annu. Rev. Phytopathol. 2004, 42, 385-414. [CrossRef]

224. Dickschat, J.S. Quorum sensing and bacterial biofilms. Nat. Prod. Rep. 2010, 27, 343-369. [CrossRef]

225. Hotinger, J.A.; May, A.E. Animal models of type III secretion system-mediated pathogenesis. Pathogens 2019, 8, 257. [CrossRef]

226. Kimura, K.; Iwatsuki, M.; Nagai, T.; Matsumoto, A.; Takahashi, Y.; Shiomi, K.; Omura, S.; Abe, A. A small-molecule inhibitor of the bacterial type III secretion system protects against in vivo infection with Citrobacter rodentium. J. Antibiot. 2011, 64, 197-203. [CrossRef] [PubMed]

227. Ochoa, T.J.; Noguera-Obenza, M.; Ebel, F.; Guzman, C.A.; Gomez, H.F.; Cleary, T.G. Lactoferrin impairs type III secretory system function in enteropathogenic Escherichia coli. Infect. Immun. 2003, 71, 5149-5155. [CrossRef] [PubMed]

228. McHugh, R.E.; O'Boyle, N.; Connolly, J.P.R.; Hoskisson, P.A.; Roe, A.J. Characterization of the mode of action of aurodox, a type III secretion system inhibitor from Streptomyces goldiniensis. Infect. Immun. 2019, 87, e00595-18. [CrossRef]

229. Tabor, D.E.; Oganesyan, V.; Keller, A.E.; Yu, L.; McLaughlin, R.E.; Song, E.; Warrener, P.; Rosenthal, K.; Esser, M.; Qi, Y.; et al. Pseudomonas aeruginosa PcrV and Psl, the molecular targets of bispecific antibody MEDI3902, are conserved among diverse global clinical isolates. J. Infect. Dis. 2018, 218, 1983-1994. [CrossRef] [PubMed]

230. Ali, S.O.; Yu, X.Q.; Robbie, G.J.; Wu, Y.; Shoemaker, K.; Yu, L.; DiGiandomenico, A.; Keller, A.E.; Anude, C.; Hernandez-Illas, M.; et al. Phase 1 study of MEDI3902, an investigational anti-Pseudomonas aeruginosa PcrV and Psl bispecific human monoclonal antibody, in healthy adults. Clin. Microbiol. Infect. 2019, 25, 629.e1-629.e6. [CrossRef] 
231. Chastre, J.; François, B.; Bourgeois, M.; Komnos, A.; Ferrer, R.; Rahav, G.; De Schryver, N.; Lepape, A.; Koksal, I.; Luyt, C.-E.; et al. Efficacy, pharmacokinetics (PK), and safety profile of MEDI3902, an anti-Pseudomonas aeruginosa bispecific human monoclonal antibody in mechanically ventilated intensive care unit patients; Results of the phase 2 EVADE study conducted by the public-private COMBACTE-MAGNET consortium in the innovative medicines initiative (IMI) program. Open Forum Infect. Dis. 2020, 7, S377-S378.

232. Pendergrass, H.A.; May, A.E. Natural product type III secretion system inhibitors. Antibiotics 2019, 8, 162. [CrossRef]

233. Sawa, T.; Kinoshita, M.; Inoue, K.; Ohara, J.; Moriyama, K. Immunoglobulin for treating bacterial infections: One more mechanism of action. Antibodies 2019, 8, 52. [CrossRef]

234. Warrener, P.; Varkey, R.; Bonnell, J.C.; DiGiandomenico, A.; Camara, M.; Cook, K.; Peng, L.; Zha, J.; Chowdury, P.; Sellman, B.; et al. A novel anti-PcrV antibody providing enhanced protection against Pseudomonas aeruginosa in multiple animal infection models. Antimicrob. Agents Chemother. 2014, 58, 4384-4391. [CrossRef] [PubMed]

235. François, B.; Luyt, C.E.; Dugard, A.; Wolff, M.; Diehl, J.L.; Jaber, S.; Forel, J.M.; Garot, D.; Kipnis, E.; Mebazaa, A.; et al. Safety and pharmacokinetics of an anti-PcrV PEGylated monoclonal antibody fragment in mechanically ventilated patients colonized with Pseudomonas aeruginosa: A randomized, double-blind, placebo-controlled trial. Crit. Care Med. 2012, 40, 2320-2326. [CrossRef] [PubMed]

236. Milla, C.E.; Chmiel, J.F.; Accurso, F.J.; Vandevanter, D.R.; Konstan, M.W.; Yarranton, G.; Geller, D.E. Anti-PcrV antibody in cystic fibrosis: A novel approach targeting Pseudomonas aeruginosa airway infection. Pediatr. Pulmonol. 2014, 49, 650-658. [CrossRef] [PubMed]

237. Sawa, T.; Ito, E.; Nguyen, V.H.; Haight, M. Anti-PcrV antibody strategies against virulent Pseudomonas aeruginosa. Hum. Vaccines Immunother. 2014, 10, 2843-2852. [CrossRef] [PubMed]

238. Jain, R.; Beckett, V.V.; Konstan, M.W.; Accurso, F.J.; Burns, J.L.; Mayer-Hamblett, N.; Milla, C.; VanDevanter, D.R.; Chmiel, J.F. KB001-A, a novel anti-inflammatory, found to be safe and well-tolerated in cystic fibrosis patients infected with Pseudomonas aeruginosa. J. Cyst. Fibros. 2018, 17, 484-491. [CrossRef]

239. Hotinger, J.A.; May, A.E. Antibodies inhibiting the type III secretion system of Gram-negative pathogenic bacteria. Antibodies 2020, 9, 35. [CrossRef] [PubMed]

240. Kinoshita, M.; Kato, H.; Yasumoto, H.; Shimizu, M.; Hamaoka, S.; Naito, Y.; Akiyama, K.; Moriyama, K.; Sawa, T. The prophylactic effects of human IgG derived from sera containing high anti-PcrV titers against pneumonia-causing Pseudomonas aeruginosa. Hum. Vaccines Immunother. 2016, 12, 2833-2846. [CrossRef]

241. Le, H.N.; Quetz, J.S.; Tran, V.G.; Le, V.T.M.; Aguiar-Alves, F.; Pinheiro, M.G.; Cheng, L.; Yu, L.; Sellman, B.R.; Stover, C.K.; et al. MEDI3902 correlates of protection against severe Pseudomonas aeruginosa pneumonia in a rabbit acute pneumonia model. Antimicrob. Agents Chemother. 2018, 62, e02565-17. [CrossRef]

242. Le, H.N.; Tran, V.G.; Vu, T.T.T.; Gras, E.; Le, V.T.M.; Pinheiro, M.G.; Aguiar-Alves, F.; Schneider-Smith, E.; Carter, H.C.; Sellman, B.R.; et al. Treatment efficacy of MEDI3902 in Pseudomonas aeruginosa bloodstream infection and acute pneumonia rabbit models. Antimicrob. Agents Chemother. 2019, 63, e00710-19. [CrossRef]

243. Proctor, C.R.; Mccarron, P.A.; Ternan, N.G. Furanone quorum-sensing inhibitors with potential as novel therapeutics against Pseudomonas aeruginosa. J. Med. Microbiol. 2020, 69, 195-206. [CrossRef]

244. Köhler, T.; Perron, G.G.; Buckling, A.; Van Delden, C. Quorum sensing inhibition selects for virulence and cooperation in Pseudomonas aeruginosa. PLoS Pathog. 2010, 6, e1000883. [CrossRef]

245. Lee, J.; Zhang, L. The hierarchy quorum sensing network in Pseudomonas aeruginosa. Protein Cell 2015, 6, 26-41. [CrossRef] [PubMed]

246. Gutiérrez-Barranquero, J.A.; Reen, F.J.; Mccarthy, R.R.; O'Gara, F. Deciphering the role of coumarin as a novel quorum sensing inhibitor suppressing virulence phenotypes in bacterial pathogens. Appl. Microbiol. Biotechnol. 2015, 99, 3303-3316. [CrossRef] [PubMed]

247. Sharma, G.; Sharma, S.; Sharma, P.; Chandola, D.; Dang, S.; Gupta, S.; Gabrani, R. Escherichia coli biofilm: Development and therapeutic strategies. J. Appl. Microbiol. 2016, 121, 309-319. [CrossRef] [PubMed]

248. Jenul, C.; Horswill, A.R. Regulation of Staphylococcus aureus Virulence. Microbiol. Spectr. 2019, 7. [CrossRef]

249. Girard, L. Quorum sensing in Vibrio spp.: The complexity of multiple signalling molecules in marine and aquatic environments. Crit. Rev. Microbiol. 2019, 45, 451-471. [CrossRef]

250. Ishaque, N.M.; Burgsdorf, I.; Limlingan Malit, J.J.; Saha, S.; Teta, R.; Ewe, D.; Kannabiran, K.; Hrouzek, P.; Steindler, L.; Costantino, V.; et al. Isolation, genomic and metabolomic characterization of Streptomyces tendae VITAKN with quorum sensing inhibitory activity from southern India. Microorganisms 2020, 8, 121. [CrossRef] [PubMed]

251. Saurav, K.; Costantino, V.; Venturi, V.; Steindler, L. Quorum sensing inhibitors from the sea discovered using bacterial N-acylhomoserine lactone-based biosensors. Mar. Drugs 2017, 15, 53. [CrossRef] [PubMed]

252. Sholpan, A.; Lamas, A.; Cepeda, A.; Franco, C.M. Salmonella spp. quorum sensing: An overview from environmental persistence to host cell invasion. AIMS Microbiol. 2021, 7, 238-256. [CrossRef] [PubMed]

253. Nakayama, M.; Shigemune, N.; Tsugukuni, T.; Tokuda, H.; Miyamoto, T. Difference of EGCG adhesion on cell surface between Staphylococcus aureus and Escherichia coli visualized by electron microscopy after novel indirect staining with cerium chloride. J. Microbiol. Methods 2011, 86, 97-103. [CrossRef]

254. Tsou, L.K.; Yount, J.S.; Hang, H.C. Epigallocatechin-3-gallate inhibits bacterial virulence and invasion of host cells. Bioorganic Med. Chem. 2017, 25, 2883-2887. [CrossRef] 
255. Brackman, G.; Breyne, K.; De Rycke, R.; Vermote, A.; Van Nieuwerburgh, F.; Meyer, E.; Van Calenergh, S.; Coenye, T. The quorum sensing inhibitor hamamelitannin increases antibiotic susceptibility of Staphylococcus aureus biofilms by affecting peptidoglycan biosynthesis and eDNA release. Sci. Rep. 2016, 6, 20321. [CrossRef] [PubMed]

256. Rasko, D.A.; Sperandio, V. Anti-virulence strategies to combat bacteria-mediated disease. Nat. Rev. Drug Discov. 2010, 9, 117-128. [CrossRef] [PubMed]

257. Jiang, Q.; Chen, J.; Yang, C.; Yin, Y.; Yao, K.; Song, D. Quorum sensing: A prospective therapeutic target for bacterial diseases. BioMed Res. Int. 2019, 2019, 2015978. [CrossRef]

258. Galante, J.; Ho, C.-Y.A.; Tingey, S.; Charalambous, B.M. Quorum sensing and biofilms in the pathogen, Streptococcus pneumoniae. Curr. Pharm. Des. 2015, 21, 25-30. [CrossRef]

259. Reen, F.J.; Gutiérrez-Barranquero, J.A.; Parages, M.L.; O'Gara, F. Coumarin: A novel player in microbial quorum sensing and biofilm formation inhibition. Appl. Microbiol. Biotechnol. 2018, 102, 2063-2073. [CrossRef]

260. De La Fuente-Núñez, C.; Reffuveille, F.; Haney, E.F.; Straus, S.K.; Hancock, R.E.W. Broad-spectrum anti-biofilm peptide that targets a cellular stress response. PLoS Pathog. 2014, 10, e1004152. [CrossRef] [PubMed]

261. Sharma, D.; Misba, L.; Khan, A.U. Antibiotics versus biofilm: An emerging battleground in microbial communities. Antimicrob. Resist. Infect. Control 2019, 8, 76. [CrossRef] [PubMed]

262. Costerton, J.W.; Lewandowski, Z.; Caldwell, D.E.; Korber, D.R.; Lappin-Scott, H.M. Microbial biofilms. Annu. Rev. Microbiol. 1995, 49, 711-745. [CrossRef] [PubMed]

263. Fux, C.A.; Costerton, J.W.; Stewart, P.S.; Stoodley, P. Survival strategies of infectious biofilms. Trends Microbiol. 2005, 13, 34-40. [CrossRef] [PubMed]

264. Costerton, J.W.; Stewart, P.S.; Greenberg, E.P. Bacterial biofilms: A common cause of persistent infections. Science 1999, $284,1318-1322$. [CrossRef]

265. Stewart, P.S. Antimicrobial tolerance in biofilms. Microbiol. Spectr. 2015, 3, 10. [CrossRef]

266. Hiemenz, J.W.; Walsh, T.J. Lipid formulations of amphotericin B: Recent progress and future directions. Clin. Infect. Dis. 1996, 22 (Suppl. S2), S133-S144. [CrossRef]

267. Drulis-Kawa, Z.; Dorotkiewicz-Jach, A. Liposomes as delivery systems for antibiotics. Int. J. Pharm. 2010, 387, 187-198. [CrossRef]

268. Li, M.; Du, C.; Guo, N.; Teng, Y.; Meng, X.; Sun, H.; Li, S.; Yu, P.; Galons, H. Composition design and medical application of liposomes. Eur. J. Med. Chem. 2019, 164, 640-653. [CrossRef]

269. Li, Y.; Yang, D.; Wang, Y.; Li, Z.; Zhu, C. Co-delivery doxorubicin and silybin for antihepatoma via enhanced oral hepatic-targeted efficiency. Int. J. Nanomed. 2019, 14, 301-315. [CrossRef]

270. Yang, X.Y.; Li, Y.X.; Li, M.; Zhang, L.; Feng, L.-X.; Zhang, N. Hyaluronic acid-coated nanostructured lipid carriers for targeting paclitaxel to cancer. Cancer Lett. 2013, 334, 338-345. [CrossRef] [PubMed]

271. Lopez-Berestein, G.; Bodey, G.P.; Frankel, L.S.; Mehta, K. Treatment of hepatosplenic candidiasis with liposomal-amphotericin B. J. Clin. Oncol. 1987, 5, 310-317. [CrossRef]

272. Ambati, S.; Ferarro, A.R.; Khang, S.E.; Lin, J.; Lin, X.; Momany, M.; Lewis, Z.A.; Meagher, R.B. Dectin-1-targeted antifungal liposomes exhibit enhanced efficacy. mSphere 2019, 4, e00025-19.

273. Fidler, I.J.; Sone, S.; Fogler, W.E.; Barnes, Z.L. Eradication of spontaneous metastases and activation of alveolar macrophages by intravenous injection of liposomes containing muramyl dipeptide. Proc. Natl. Acad. Sci. USA 1981, 78, 1680-1684. [CrossRef]

274. Wicki, A.; Rochlitz, C.; Orleth, A.; Ritschard, R.; Albrecht, I.; Herrmann, R.; Christofori, G.; Mamot, C. Targeting tumor-associated endothelial cells: Anti-VEGFR2 immunoliposomes mediate tumor vessel disruption and inhibit tumor growth. Clin. Cancer Res. 2012, 18, 454-464. [CrossRef]

275. Stathopoulos, G.P.; Antoniou, D.; Dimitroulis, J.; Stathopoulos, J.; Marosis, K.; Michalopoulou, P. Comparison of liposomal cisplatin versus cisplatin in non-squamous cell non-small-cell lung cancer. Cancer Chemother. Pharmacol. 2011, 68, 945-950. [CrossRef]

276. Nightingale, S.D.; Saletan, S.L.; Swenson, C.E.; Lawrence, A.J.; Watson, D.A.; Pilkiewicz, F.G.; Silverman, E.G.; Cal, S.X. Liposomeencapsulated gentamicin treatment of Mycobacterium avium-Mycobacterium intracellulare complex bacteremia in AIDS Patients. Antimicrob. Agents Chemother. 1993, 37, 1869-1872. [CrossRef] [PubMed]

277. Alhajlan, M.; Alhariri, M.; Omri, A. Efficacy and safety of liposomal clarithromycin and its effect on Pseudomonas aeruginosa virulence factors. Antimicrob. Agents Chemother. 2013, 57, 2694-2704. [CrossRef] [PubMed]

278. Dos, B.; Rodrigues, S.; Kanekiyo, T.; Singh, J. ApoE-2 brain-targeted gene therapy through transferrin and penetratin tagged liposomal nanoparticles. Pharm. Res. 2019, 36, 161.

279. Agrawal, M.; Tripathi, D.K.; Saraf, S.; Saraf, S.; Antimisiaris, S.G.; Mourtas, S.; Hammarlund-Udenaes, M.; Alexander, A. Recent advancements in liposomes targeting strategies to cross blood-brain barrier (BBB) for the treatment of Alzheimer's disease. J. Control. Release 2017, 260, 61-77. [CrossRef]

280. Bakker-Woudenberg, I.A.J.M.; Ten Kate, M.T.; Guo, L.; Working, P.; Mouton, J.W. Improved efficacy of ciprofloxacin administered in polyethylene glycol-coated liposomes for treatment of Klebsiella pneumoniae pneumonia in rats. Antimicrob. Agents Chemother. 2001, 45, 1487-1492. [CrossRef]

281. Henry, B.D.; Neill, D.R.; Becker, K.A.; Gore, S.; Bricio-Moreno, L.; Ziobro, R.; Edwards, M.J.; Mühlemann, K.; Steinmann, J.; Kleuser, B.; et al. Engineered liposomes sequester bacterial exotoxins and protect from severe invasive infections in mice. Nat. Biotechnol. 2015, 33, 81-88. [CrossRef] [PubMed] 
282. Lombardi, C.; Tolchard, J.; Bouillot, S.; Signor, L.; Gebus, C.; Liebl, D.; Fenel, D.; Teulon, J.-M.; Brock, J.; Habenstein, B.; et al. Structural and functional characterization of the type three secretion system (T3SS) needle of Pseudomonas aeruginosa. Front. Microbiol. 2019, 10, 573. [CrossRef] [PubMed]

283. Shumba, P.; Shambat, S.M.; Siemens, N. The role of streptococcal and staphylococcal exotoxins and proteases in human necrotizing soft tissue infections. Toxins 2019, 11, 332. [CrossRef] [PubMed]

284. Bhakdi, S.; Tranum-Jensen, J.; Sziegoleit', A. Mechanism of membrane damage by streptolysin-O. Infect. Immun. 1985, 47, 52-60. [CrossRef] [PubMed]

285. Craig-Mylius, K.A.; Weiss, A.A. Antibacterial agents and release of periplasmic pertussis toxin from Bordetella pertussis. Antimicrob. Agents Chemother. 2000, 44, 1383-1386. [CrossRef]

286. Berry, A.M.; Lock, R.A.; Hansman, D.; Paton, J.C. Contribution of autolysin to virulence of Streptococcus pneumoniae. Infect. Immun. 1989, 57, 2324-2330. [CrossRef] [PubMed]

287. Sécher, T.; Dalonneau, E.; Ferreira, M.; Parent, C.; Azzopardi, N.; Paintaud, G.; Si-Tahar, M.; Heuzé-Vourc'h, N. In a murine model of acute lung infection, airway administration of a therapeutic antibody confers greater protection than parenteral administration. J. Control. Release 2019, 303, 24-33. [CrossRef] [PubMed]

288. Song, Y.; Baer, M.; Srinivasan, R.; Lima, J.; Yarranton, G.; Bebbington, C.; Lynch, S.V. PcrV antibody-antibiotic combination improves survival in Pseudomonas aeruginosa-infected mice. Eur. J. Clin. Microbiol. Infect. Dis. 2012, 31, 1837-1845. [CrossRef] 